\title{
اصلاح الفرد في سورة النور (دراسة وصفية تحليلية)
}

إعداد: د. عائشة شريف محمد أحمد عثمان

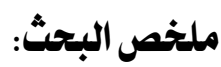

تهدف هذه الدراسة إلى تسليط الضدوء على اهتمام سورة النور بإصلاح الفرد اصلاحسا شامـلا يجعل منهـ انسانا صالحا ليقوم بههمهة الاستخللاف في الأرض و إعمارها. وقد ذكر الله تعالى في كتابه و صدايا عظيمهة وحكما بليغة و آدابا عالية، الغرض منها جهيعا صون الإنسان عن الزلل والخطأ ومن ثم حمايته من الأخطار، فجاءت هذه السورة بجملة من تلك الآداب الفردية التي إذا توافرت في الفرد والتزم بها لانتشرت الفضيلة وعم الخير في الهـجتهـع، خاصدة وأننا نعيش في زمان كثرت فيـه الهشكلات و الابتلاءات و اختلط فيـه الحابل بـالنابل وعمـت الفوضى. فجاء هذا البـحث محاولا أن يلخص أهم الآداب الفردية التي أكدت السورة عليه. كها أظهرت الدراسـة تفرد القر آن بهنهج تربوي شـامل متكامل فهو يهتم بجمهيع جوانب النفس الإنسانية.

\section{Abstract}

This study aims to shed light on Surat Al-Nur's interest in comprehensively reforming the individual, making him a good person to carry out the task of succession in the land and its reconstruction. God Almighty mentioned in his book great commandments, eloquent wisdom and high etiquette, all of which are intended to protect man from error and error, and then protect him from dangers, This surah came with a set of those individual etiquette which, if available in the individual and adhered to them, would spread virtue and goodness in society, especially since we live in a time when problems and tribulations abounded, the barrages were mixed with nebulae and chaos prevailed. This research came in an attempt to summarize the most important individual etiquette that the surah emphasized. The study also revealed the uniqueness of the Qur'an with a comprehensive, integrated educational approach, as it deals with all aspects of the human psyche. 
المقدمة: 2 - 2

الحمد لله الذي خلق الإنسـان ووكرمـه على سـائر مخلوقاته بنعمهة العقل وارسل له رسلا يهتدي بهديهه و منههاجا يسير عليه في حياته. والصلاة والسلام على الهبعوث رحمهة للعالهين سيدنا محمد وعلى آله و صسحبـ أجمعين. - 1 آله

عنى الإسـلام بالإنسان الفرد عناية لامثيل لها، بغية ان يهيئه ليكون أهلا كلاستخلاف في الأرض و يعمـر الكون وبرزت هذه العنايلة الإلهيـة مـنذ الخلق و التكوين، حين خلق الله تعالى آدم عليه السـلام بيديه ونفخ فيه مـن روحه و منـحه العقل والحواس فبـان بهذا أنه مخلوق كريه على الله تعالى ثم تبعته العناية الإلهية حين قضى الله تعالى ان يكون خليفة له في الأرض، وقد توجت هذه العناية بشريعة الإسلام وما تضمنته من هدايات وتوجيهات تخص الفرد الهسلهم كادت تستغرق العهد الهكي كله، ولهم يغفلها العهد المدلني كها في سورة النور مـوضوع الدراسـة، وقد هدفت كلها إلى بناء شخصيـة الفرد الهسلم، متزنة مستقلة، تجمـع بين ما استودع فيها مـن رغبات ونزعات، وبين مـا أنيط بها من مسؤو ليات على مستوى الفرد و الجمهاعات، و هذا مـا جعل مـن هذا الإنسان -بحق - مسخلوقا متميزا، و صسار خليقا بأن يصبـح خليفة في الأرض و أهلا للقيام بواجباته تجاه نفسـه و تجـاه مستمعـه .

"و مهـا أسهم في تحقيق هذه الغاية العظهى والههمهة الأسهى، أن الله تعالى أودع في الإنسـان نزعتين متتباينتين في الظاهر لكنهما متتكاملتان(1)، وهها: النزعة الفردية وهي التي تجعله يحب الخير لنفسـه ويدفع الشر عنها، و يحر ص على تحقيق ذاته، والنزعة الاجتهاعية وهي التي تدفعه إلى صف الجهاعة وحضن الهـتمهع، لأن الله تعالى جعل بحكمته حاجة الفرد إلى الفرد، كحاجة العضو إلى العضو في الجسد الواحد.

(1) علهم الاجتهاع و المجتمع الاسلامي، د. مصطفى شاهين، طا، العاهـ،|99|م، ص10. 


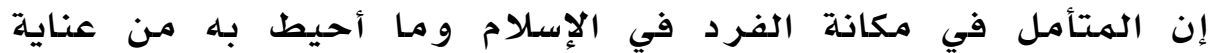

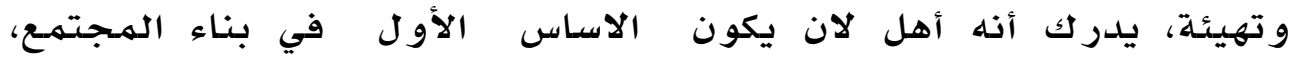

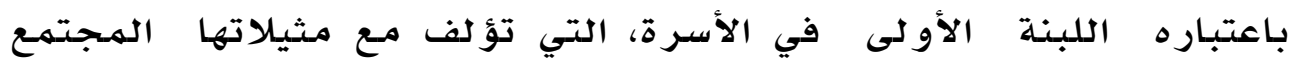

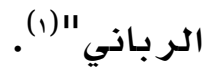

لقد اهتهم القر آن الكريهم بتنهية الإنسان إذ هو خليفة الله في أرضه

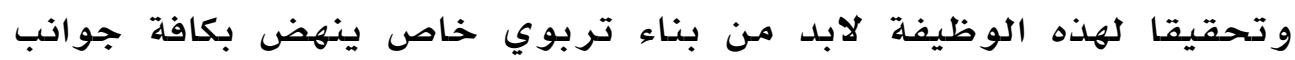
الإنسان الروحية و الجسمية و العقلية و والوجدانية و السلوكية ولونية والأخلاقية.

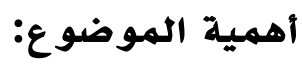

تكمن أهمية الهوضوع في التعرف على أهمية الهوجهات الإصلاحية

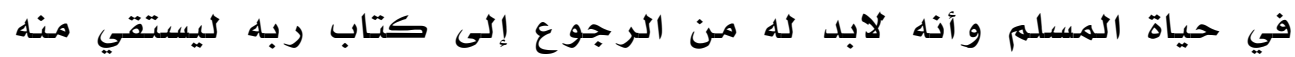
القيم الإصدلاحية.

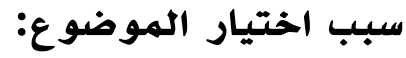
ا ـ بيان اهتمـام القر آن الكر يهم ببناء الفرد و إصلاحه.

r. الرغبة في تذكير الناس بالاهتمام بكتاب ربهم تلاوة وتفكرا

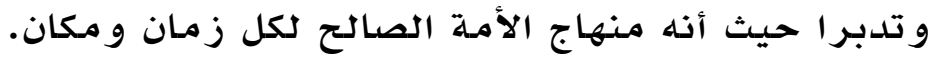

\section{مشكلة البحث:}

تكمن مشكلة البحث في التعرف على أهمية القيم الإصلاحية في حياة

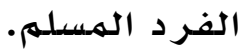

حيث تتهثل في الإجابة على الأسئلة الآتية: ا ـ ما مفهوم الإصلاح الفردي في الإسـلام؟

r. ما القيم والموجهات الإصلاحية المستنبطة من سورة النور؟ 
r. مـا أثر هذه القيهم والمبـادئ الإصلاححية في حياة الفرد المسله؟

الدراسات السابقة:

- الهضامين الرورحية والاجتهاعية و النفسية ودلالاتها التربوية في سورة النور،

بحث من إعداد: إيهمان محمد رضنا ونورة بنت محمد بن فهد الجليل، مـجلة دراسـات علوم الشر يعة والقانون مجلد بع، ملحق r،

- الآداب الاجتهماعية في سورة النور - دراسلة موضوعية -د. منهل يحي اسـماعيل، استإذ مسـاعد في قسمر الشريعة، كليـة العلوم الإسلامـية،

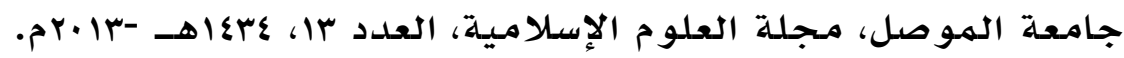
- كها ان هناك العديد من الدراسـات في سورة النور متفرقة على شبكة الانتر نت.

\section{منهج البحث:}

سأسلك في هذا البـحث الهنهج الوصفي التحليلي الاستقر ائي، حيث اتبع فيـ الخطوات التالية

$$
\text { ا ا. عزو الآيات إلى سورها. }
$$

r. تخريج الأحاديث من مظانها.

r. الرجوع إلى مصادر الدر اسـة الأصلية .

ع.عزو الأفكار و الآر اء إلى أصحابها.

$$
\text { هيكل البحث (تبو يبـه): }
$$

قهت بتقسيهم البحث إلى ثلاثة مباحث وتحت كل مبحث عدد من المطادب 
الهطلب الأول: تعريف الإصلاح لغة و اصطلاحها.

$$
\text { الهطلب الثاني: بين يدي السـورة. }
$$

المبحث الثاني: الإصلاح الأخلاقي للفرد في سورة النور

الهطلب الأول: تعريف الأخلاق لغة و اصطلاحا

الهطلب الثاني: حسن الظن بالمؤمنين

المطلب الثالث: التثبت و تحري الحق

الهطلب الر ابع: الصبر وضبط النفس

الهطلب الخامس: الاستجابة للحق و الر جوع للفضيلة

المبحث الثالث: الإصلاح السلوكي للفرد في سورة النور:

الهطلب الأول تعريف السلوك لغهة و اصطللحا

الهطلب الثاني: غض البصر

الهطلب الثالث: حفظ الفرج

الهطلب الر ابع: حفظ اللسان

الهطلب الخامس: الحشمهة و العفة

الهطلب السـادس: الغيرة على العرض و الحصر مـات 


\section{المبحث الأول: تعريف الإصلاح لغة واصطلاحا}

الاطلب الأول: تعريف الإصلاح لغة واصطلاحا:

أ/ الإصلاح لغة ضد الفساد تقول صلح الشيء يصلح صلاحاً وصلوحاً،

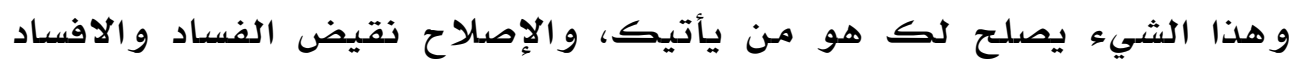

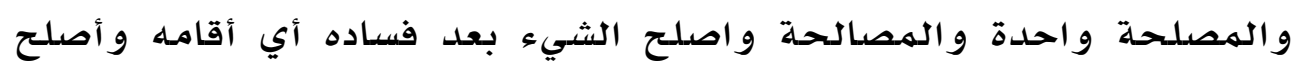

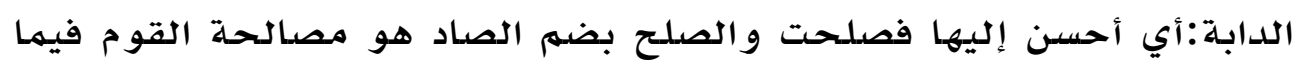
بينهم و قوم صلوح متصالحي احن الحون (1).

الإصدلاح لغة من الفعل الثلاثي: صلح قال الرازي الصدلاح ضد الفساد

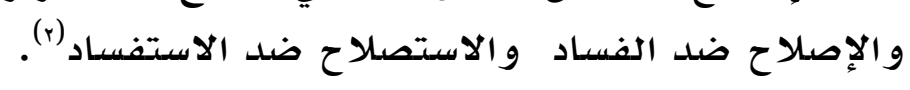

و الإصلاح مصدر أصلح التحسين، الاتيان بما هو صالح، أصلح الرجل أرها

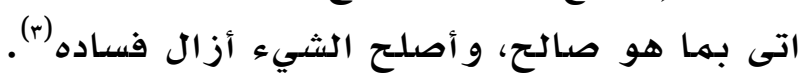
ب/ الإصلاح اصطلاحاً:

الصدلاح هو سلوك طريق الهدى، وقيل: هو استقامة الحال على مـا

يدعو إليه من حقوق العباد وحقوق الله تعالى (๕).

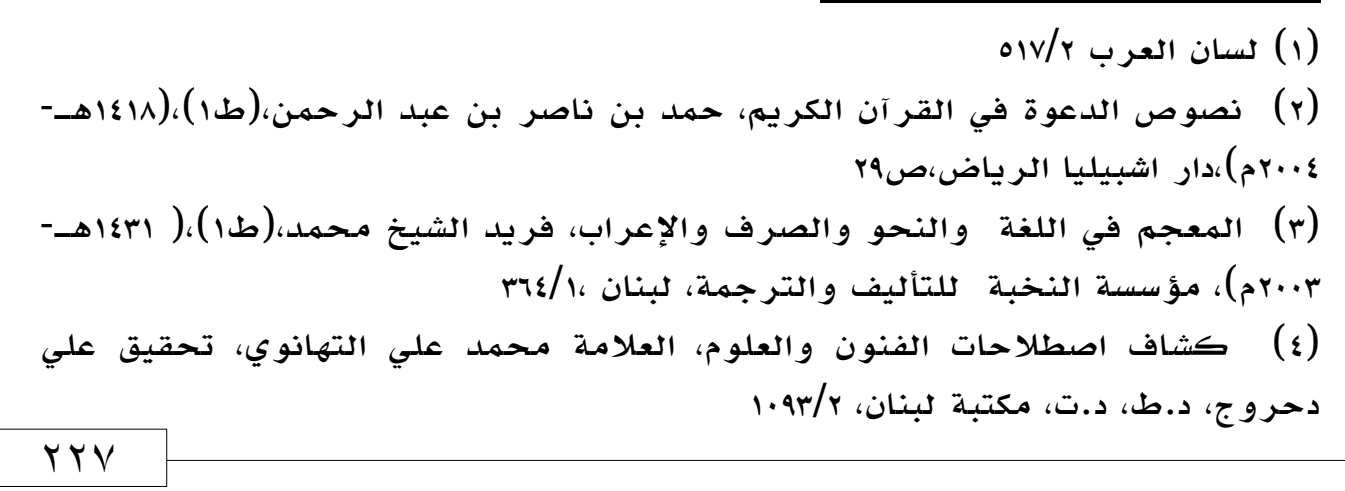


أو لا اسم السورة:

سميت سورة النور لتنويرها طريق الحياة الاجتماعية للناس وبيان

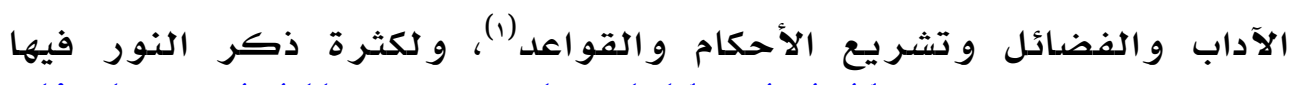

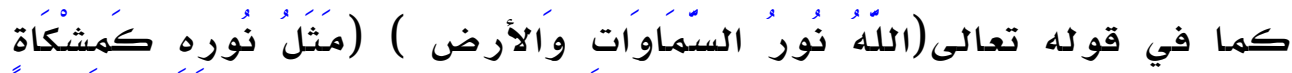

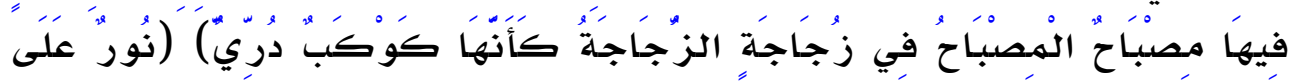

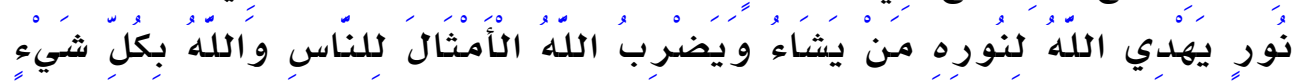

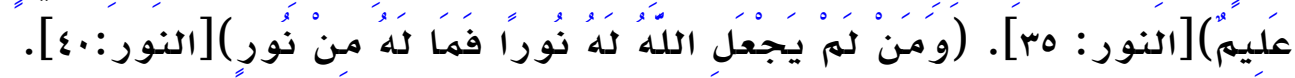

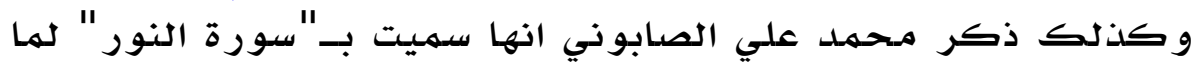

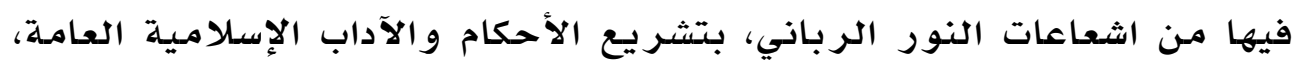

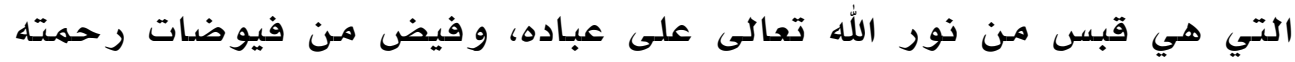
وجوده (ن)

وردت سورة النور في الجزء الثامن عشر من القرآن النهريهم بين

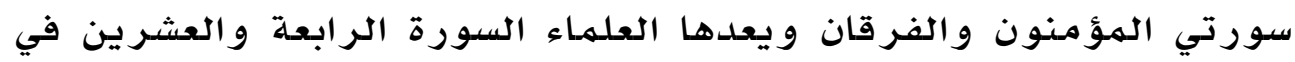

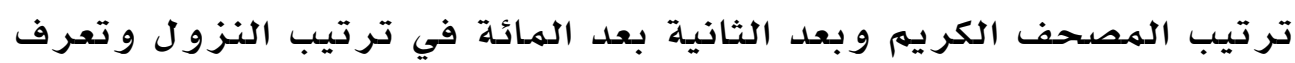

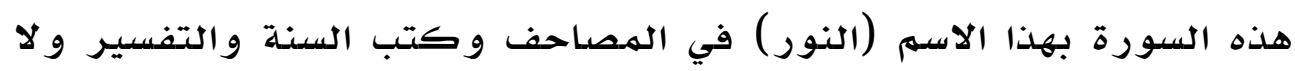
يعرف لها اسهم آخر غيره و لكن الفاتحة تشارك الك هذه السورة في اسهمها

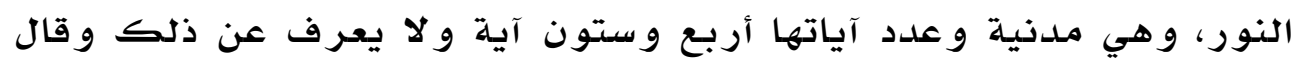

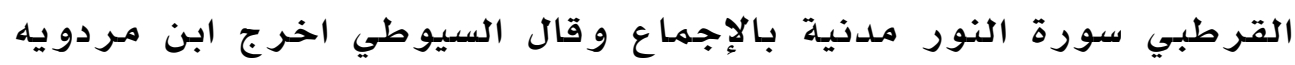

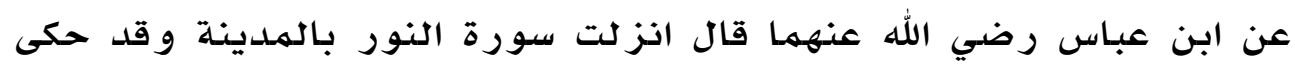

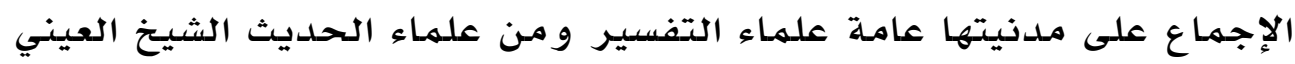

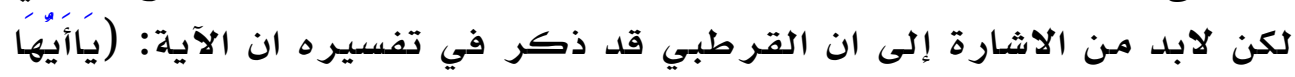

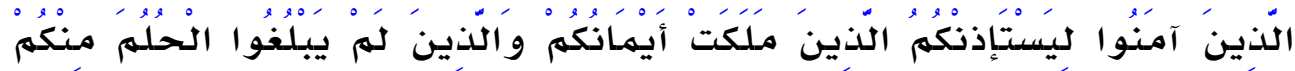

(1) التفسير المنير في العقيدة والتشريع والمنهج، وهبة الزحيلي، طه، بrعاهـ،ه...rم،

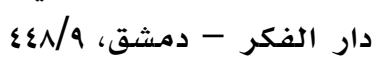

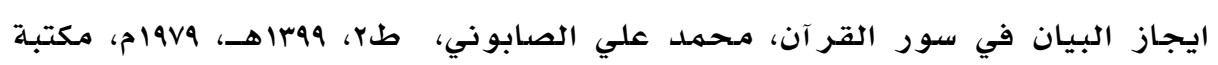




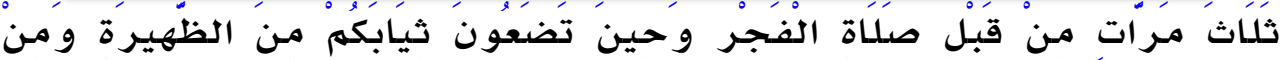

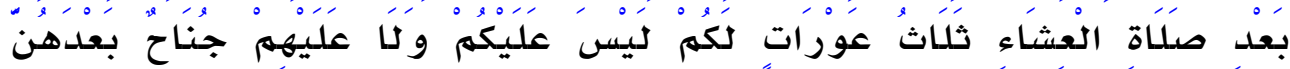

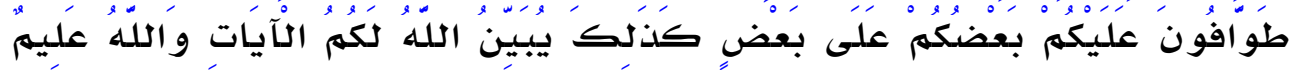

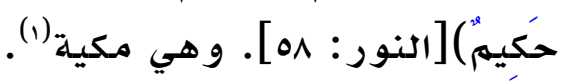

وقد تبعـه على ذلك عدد مـن العلهاء وقول القرطبي هذا غريب جدا وو جـه الغرابة فيه أمـران الأمـر الأول: هو أن القرطبي نفسه قد حكى الإجماع على مدنيتها في أول السورة وقد تقدم ذكر ذلك.

الأمر الثاني: ان سبب النزول الذي ذكره القرطبي صريح انها مدنية

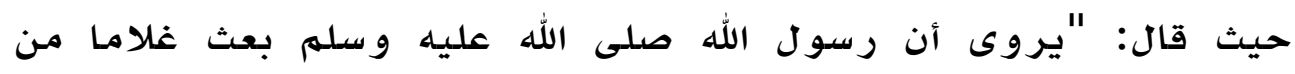
الأنصسار يقال له مـرجح إلى عهـر بن الخطاب رضي الله عنـه ظهيرة ليدعوه ووجده نائها قد أغلق عليه الباب فدق عليه الغلام الباب فناداه ودخل فاستيقظ عمـر وجلس فانكشف منـه شيء فقال عهر: "وودت ان الله نهى أبناءنا و نسـاءنا وخدمنا من الدخول علينا في هذه الساعات إلا بإذن ثم انطلق إلى الرسول صلى الله عليـه وسلهم فوجد هذه الآية قد أنزلت فخر

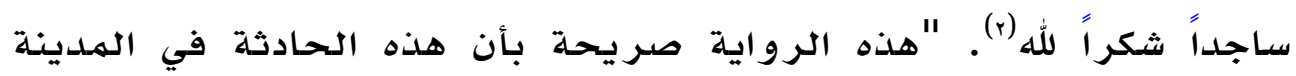

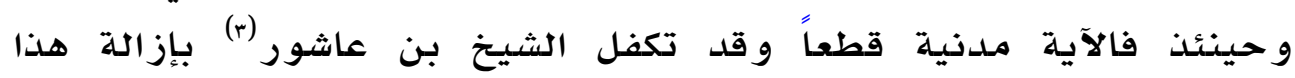
الاستغر اب فقال: "لعل تحريفا طر أ على النسخ من تفسير القرطبي وان جواب الكلهمة(وهي محكهة)، بـل مـن مكية أي غير نسوخ حكهها وقد وقعت وقدي هذه العبارة في تفسير بن عطية قال: "هي محكمهة."(ع)،كها ان النهية آلية

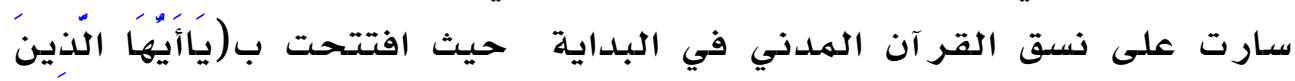

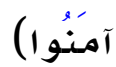

(1) عمدة القارئ شرح صديح البخاري للشيخ بدر الدين محمد مدمهود العيني

$$
\begin{aligned}
& \text { (ت100هـ،)، دار الفكر بيروت لبنان، صدارئ }
\end{aligned}
$$

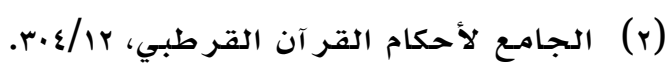

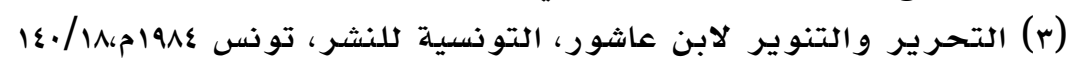

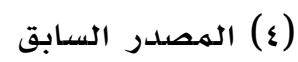




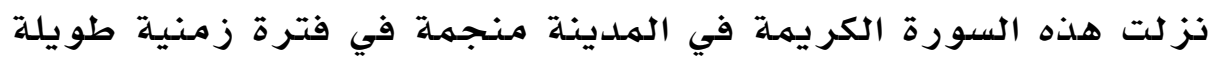

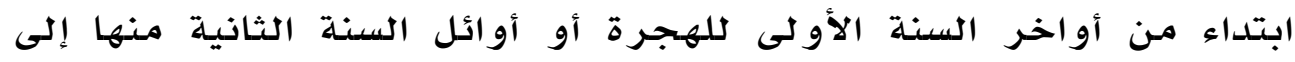

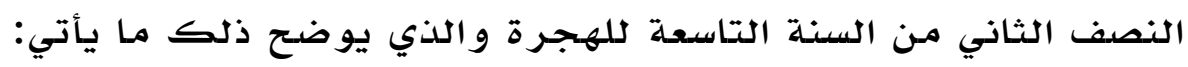

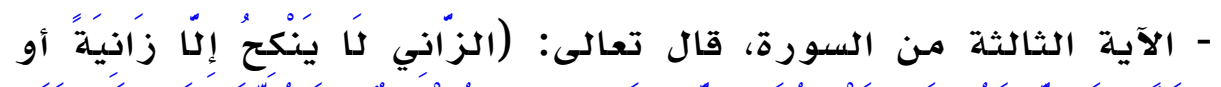

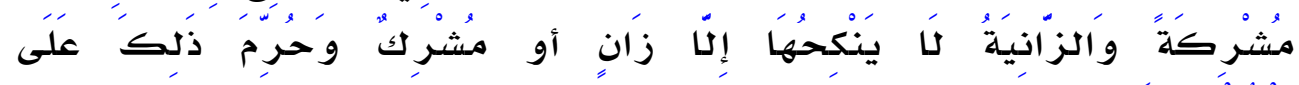

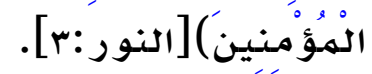

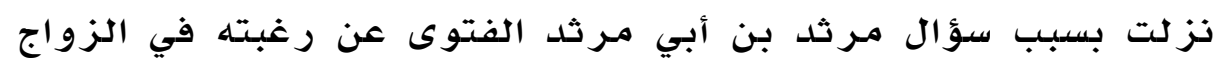

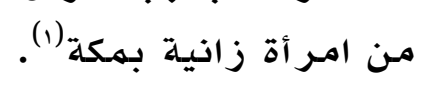

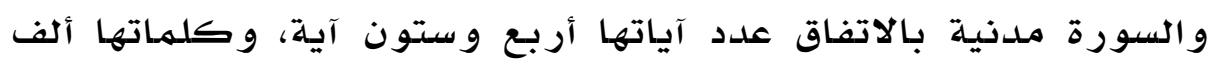

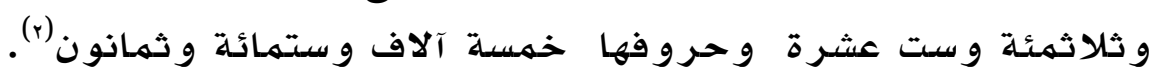

$$
\text { أغر اض و مقاصد السورة: }
$$

إن مقصود السورة هو مدلول اسهمها الذي اودعه الله تعالى فيها، وهو

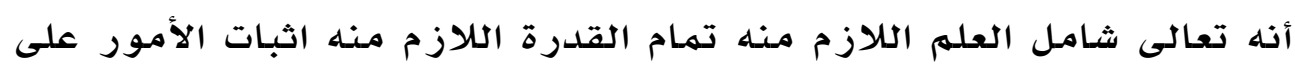

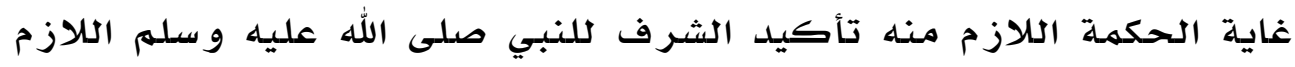

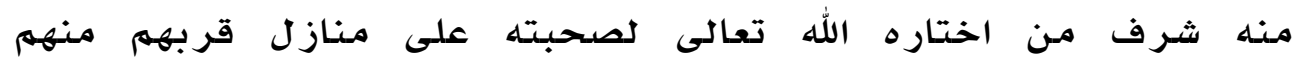

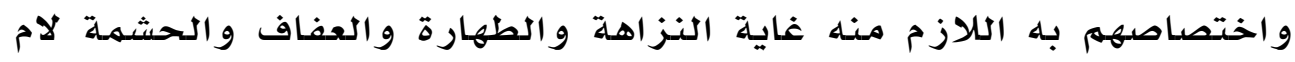

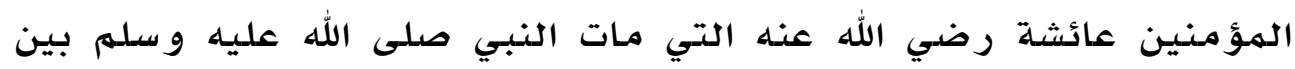
سحر ها ونحر ها و هو ر راضن عنهاه ونها.

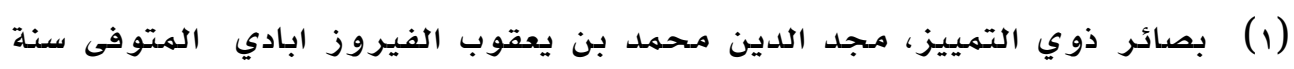

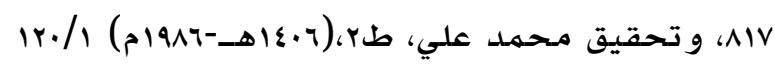

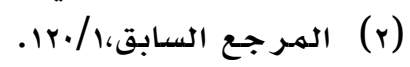


و هذه سورة الآداب و الأخلاق والتربية الإسـلاميـة، الهادفة إنها الأخلاق

و القيهم المنبثقة عن ايهان الهؤمن بالله إذا دخل نور الإيهان في القلب

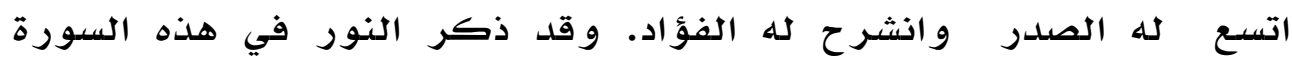
بلفظه كها ذكر آثاره ومظاهره في القلوب والارواح مهثل هذه الآثار في بيان الفرائض و الأحكام التي يقوم عليها بناء السورة وهي احكام و آداب نفسية عائلية وجماعية تؤدي إلى طهارة الفرد و سلامهة الهـتهـع حيث تبدأ بإعلان حاسهم وقوي على تقدير هذه السـورة وفرضها بكل مـا فيها من تكاديف و آداب و اخلاق (1)

و كذلك اشتملت سورة النور على كثير من الأغر اض منها:

* عقاب الذين يقذفون الهحصنات.

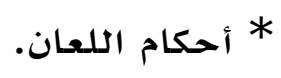

* الزجر عن حب اشـاعة الفواحش بين المؤمنـين و المؤمنـات. * الأمـر بالصفح عن الإذى عند القدرة عليه. * أحكام الاستتُذان عند دخول بيوت الناس الهسكونة، ودخول البيوت غير المسكو نة.

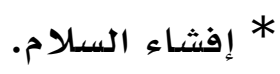
* تحر يـم البغاء الذي كان شائعا في الجـاهليـة. * الأمـر بالعفاف. * التحذير من الوقوع في حبائل الشيطان. 
و تخلل ذلك و صف عظمة الله تعالى و بدائع مصنو عاته، و فيها من منن

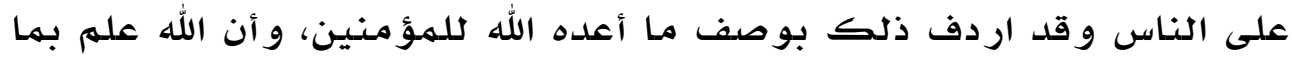

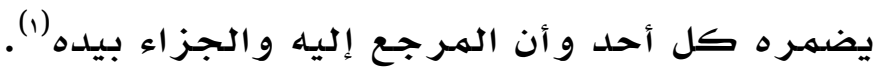

لقد عالجت السورة أغلظ ما في الكيان البشري ليرققه ويطهره

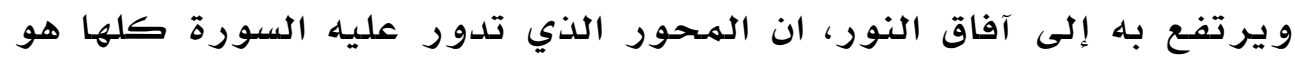

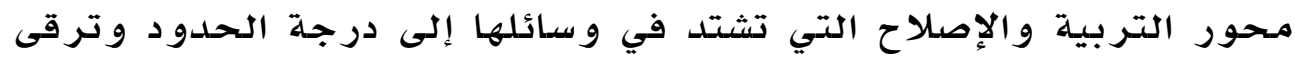

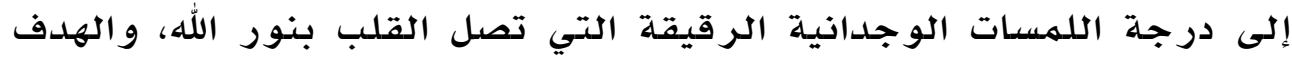

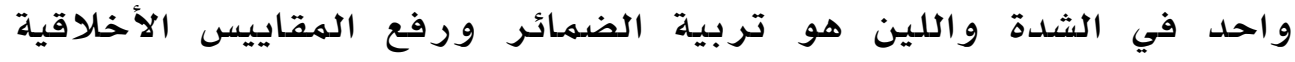

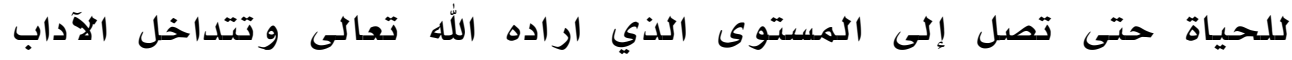
النفسية الفردية و آداب البيت والأسىرة، و آداب الجهماعة والقيادة، بوصفها

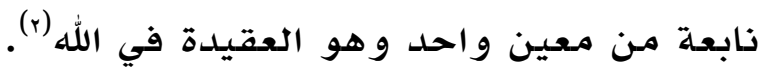

و تختهم السورة الكريمة - بعد ذكر طائفة من الأحكام التشريعية بوجوب احتر ام أمر الرسول صلى الله عليه وسلهم وتعظيمـه و إجلاله لأنه

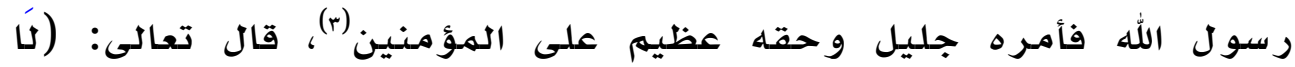

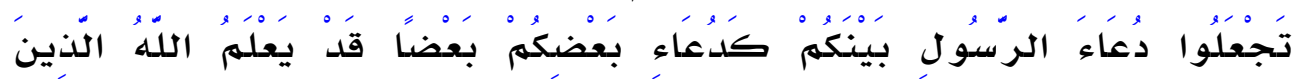

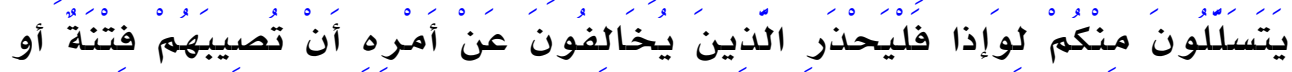

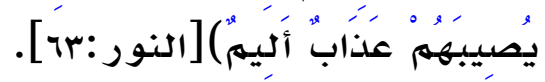
و هكذا تختم السورة بتعليق القلوب والأبصار بالله تعالى، وتذكيرها

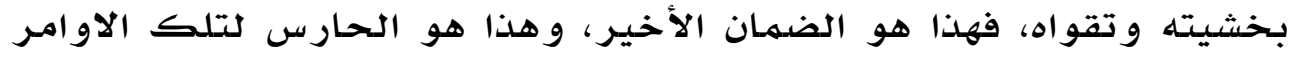

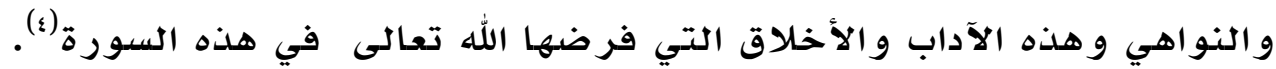

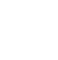

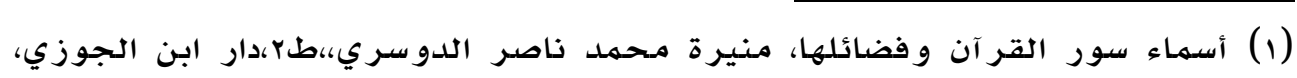

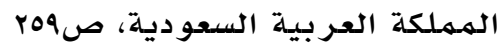

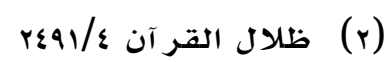

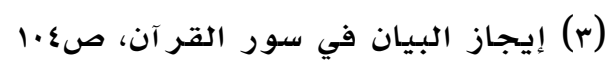

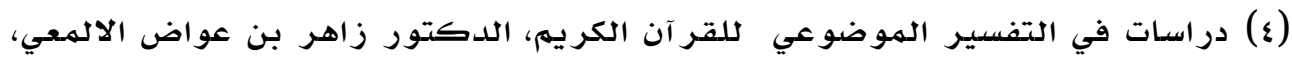
TMT

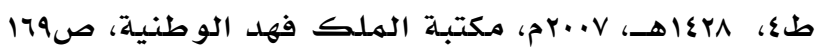




\section{المبحث الثاني: الإصلاح الأخلاقي للفرد في سورة النور}

الاطلب الأول تعريف الأخلاق لغة واصطلاحا:

\section{أو لا تعريف الأخلاق لغة:}

الأخلاق جمع خلق، والخلق اسم لسجية الإنسان وطبيعته التي خلق عليها (1)

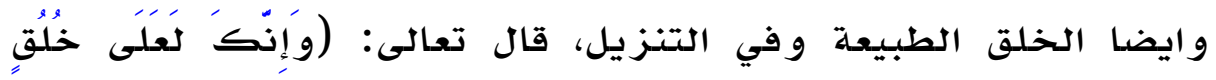

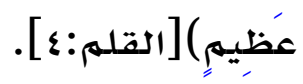

و الجمـع أخلاق، لا يكسر على غير ذلك، والخلق: السجية. يقال: خالق

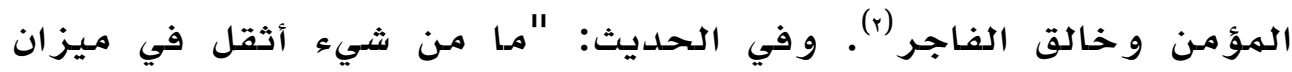

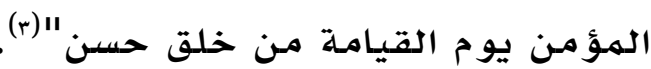

و قيل وحقيقة الخلق في اللغة هو ما يأخذ به الإنسان نفسه من الآدب يسمى خلقا لأنه يصير كالخلقة التقل فيه. إذا الخلق في اللغة لا يخر ج عن المعاني الآتية: *السجية: أي الطبيعة المتمكنة في النفس سواء كانت حسنة أو قبيـحة . * العادة و الطبيعة و الدين و المرووة. ثانيا: تعريف الخلق اصطلاحا:

(1) جمهرة اللغة، ابوبكر محمد بن الحسن بن دريد الازدي، (المتوفى:ابrاهـ)، تحقيق:

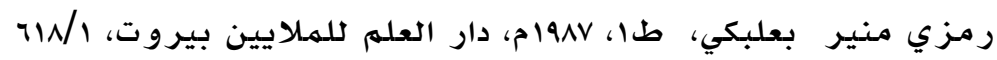

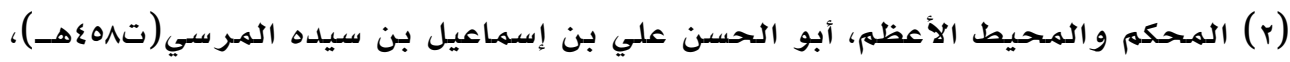

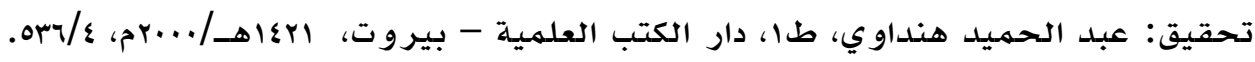

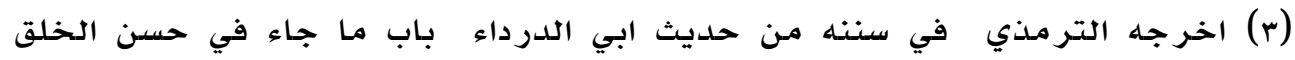
rTr

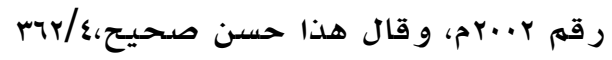


عرف العلماء الأخلاق بتعريفات متعددة بيانها كالآتي:

- عرف الجر جاذي الخلق بأنه:" عبارة عن هيئة للنفس راسخة تصدرر عنها الأفعال بسهو لة ويسر مـن غير حاجة إلى فكر وروية، فان كانت الهيئة بحيث تصدر عنها الأفعال الجميلة عقلا و شر عا بسهو لة، سهيت الهيئة: خلقا حسنا، وإن كان الصسادر منها الافعال القبيحة، سهيت الهيئة خلقا سيئاً (1). - و من العلهـاء الهحدثين من عرف الخلق بأنه: "صفة مستقرة في النفس فطرية أو مكتسبـة ذات آثار في السلولك مـحمودة أو مدذمومـة(r). - امـا علهم الأخلاق فقد عرف بانه:" علهم موضدوعه أحكام قيميـة تتعلق بالأعمال التي توصف بالحسن أو القبح "(r). إذا يهكن أن يعرف علم الأخلاق الإسـلامي بأنه: "علهم يبحث في الأحكام و الهعايير والهبادئ التي عن طريقها يو صف السلوك الإنساني بأنه فضيلة فيقتنى أو أنه رزيلة فيتخلى عنها، حتى تزكو النفس الإنسانية، و ذلك على أسـاس من الوحي الذي جـاء بـه الرسول صـلى الله عليه و سـلم (ء). المطلب الثاني: حسن الظن بالمؤمنين:

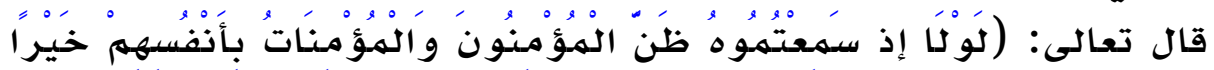

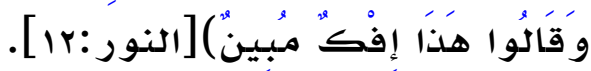
ان من مقتضى الإيهان أن يحب المـرء لأخيه مـا يحب لنفسـه، و مـن حبـ

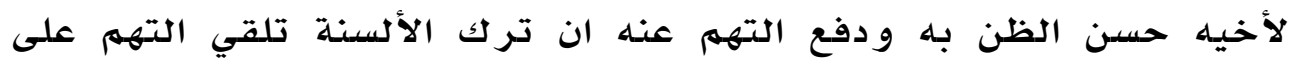

(1) (1اب الثقافة الاسلامية، اعداد مجمهوعة من العلماء والباحثين، مركز الرعاية

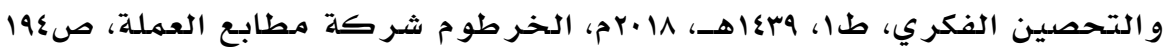

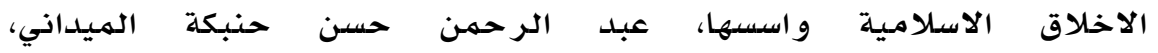

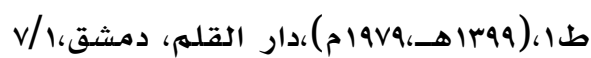

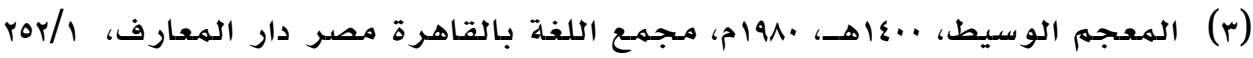
الاخلاق في الاسلام بين النظرية والتطبيق، محفوظ عزام، دار الهاني للنشر 
الهـحصنات - وهن العفيفات الحرائر ثيبات وأبكارا - بلدون دليل قاطع، يترك الهـجال فسيحا لكل من شـاء أن يقذف بريئة أو بريئا بتلك التههمة النكر اء، ثم يهضي آمنا؛ فتصبسح الجماعة وتهسي، و وإذا أعر اضها مهرحة وسهعتها ملوثة ؛وإذا كل فرد فيها متههم أو مهـدد بالاتهام؛ وإذا كل زوج فيها شاك في زوجه وكل رجل شاك في أصله، ووكل بيت مهدد بالانهيار. و هي حالة مـن الشك والقلق والريبـة لا تطاق.

ذلك إلى أن اطراد سهماع التهم يوحي إلى النفوس الهتحرجة من

ارتكاب الفعلة أن جو الجماعة كله ملوث، وأن الفعلة فيها شائعة؛ فيقدم عليها من كان يتحرج منها، وتهون في حسـه بكثرة تردادها، وشعوره بان كثير ين غيره يأتو نها (1).

و ما جاء في قصدة الإفك فيها آداب منها: هلا حين سهعتم أيها الهؤمنون كلام الافاكين في أم الهؤمنين عائشة، ظننتهم بها خيرا بهقتضى الإيهان الذي يحهل على حسن الظن؛ وهلا بادرتم إلى القول

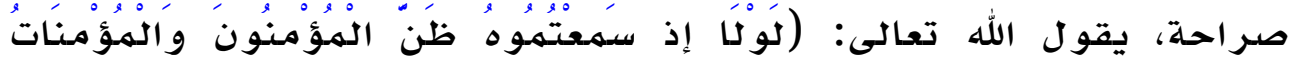

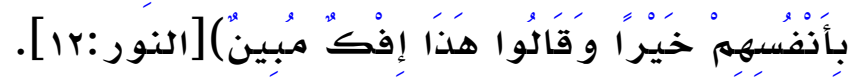
أي كذب مستتلق، واضدح مكشوف على أم المؤمسنين رضي الله عنها؛ فإنها جاءت راكبة على راحلة صفوان بن الهعطل في وقت الظهيرة، و الجيش كله يشاهد ذلك، ولو كان فيه شيء من الريبـة، لما تم الأمر

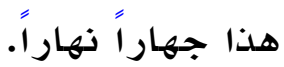

وهلا أتى الافاكون على ما قالوا بأربعة شهود يشهدون على ثبوت التهمهة، و صدحة المعاينة، فحين له يأتوا بالشهود لإثبات التهمهة، فأو لئك في حكم الله كإذبون فاجرون، وهذا من الزواجر، وومن التقصير في القيام 
بعبء الاثبـات، عمهلا بالقاعدة الكبرى: "البينـة على من ادعى، واليهين على

من أنكر "(1) (1)

\section{الاططلب الثالث: التثبت وتحري الحثق.}

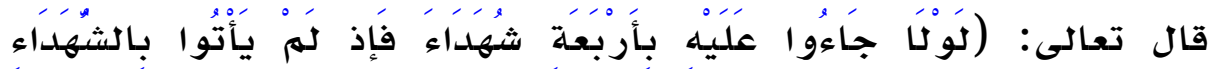

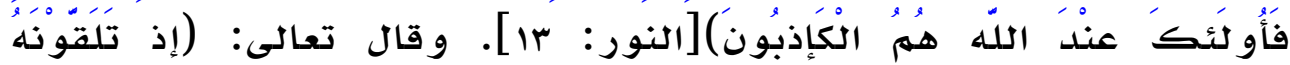

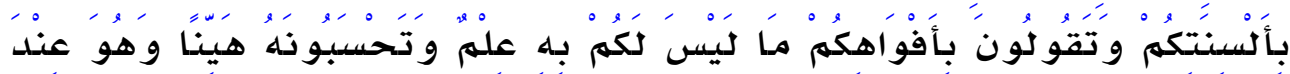

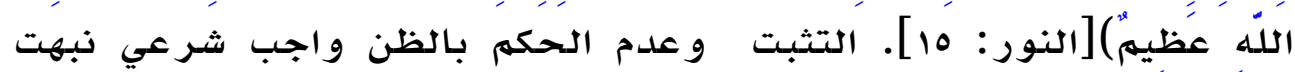
إليه السورة و أكدت عليه، كها حذرت مـن اغفاله تحريهم ظن السـوء، وانه

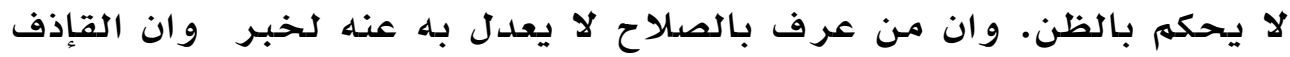

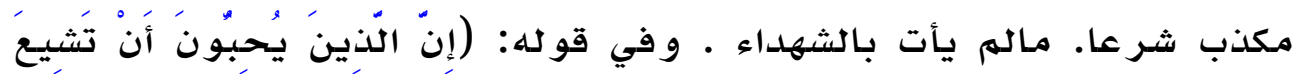

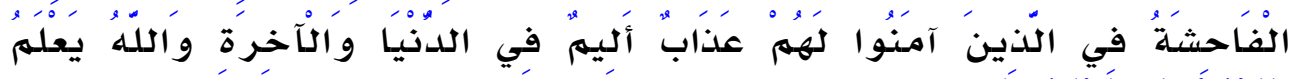

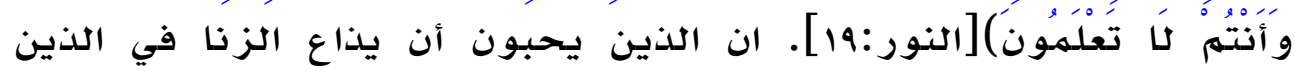
صدقوا بالله ورسوله، ويظهر ذلك فيهم لهم عذاب أليهم، يقول: لهم عذاب وجيع في الدنيا، بـالحد الذي جعله الله حدا لرامي الهـصنسات والهـحصنين إذا رمـوهم بذلك، وفي الآخرة عذاب جهنهم ان مات مصر ا على ذلك غير تائب(ץ) الحثث على ستر الهؤمن و عدم هتكه. أخرج ابن أبي حاتهم عن خالد ابن معدان، قال: "مـن حدث بهـا أبصرت عيناه وسهعت إذناه فهو مـن الذين يحبون أن تشيع الفاحشة في الذين آمنوا.." وأخرج عن عطاء قال: "من

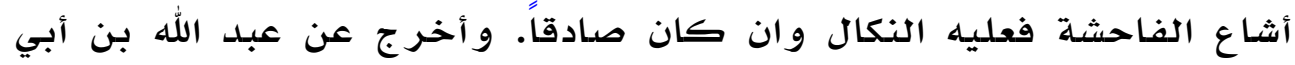

(1) التفسير الوسيط، أ.د. وهبة الزحيلي، طا، rY\&اهـ،ا..بم، دار الفكر المعاصر، بيروت لبنان، iVra-ivro/r

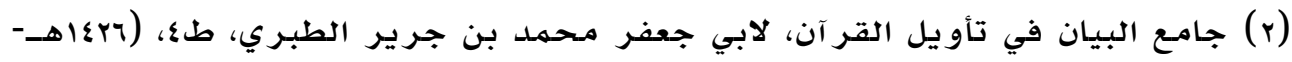
rAV/9 r... 
زكريا، أنه سئل عن هذه الآية فقال: هو الرجل يتكلهم عنده في الرجل، فيشتهي ذلك و لا ينكر عليه (1). الاطلب الرابع: الصبر وضبط النفس:

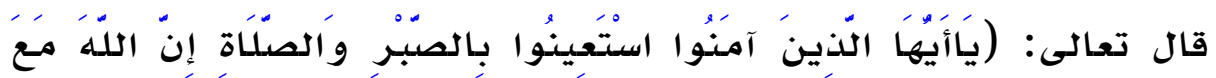

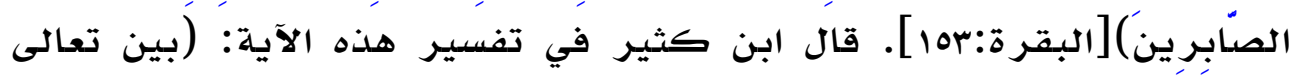

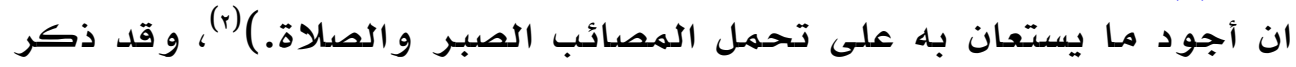

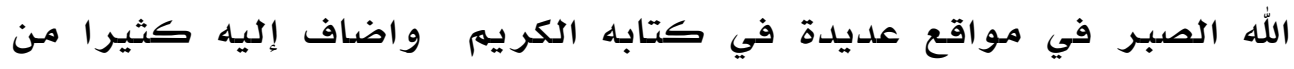

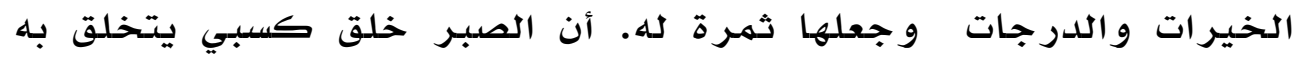
العبد، وهو حبس النفس عن الجزع و الهلع و التشكي، فيحبس النفس عن التهره

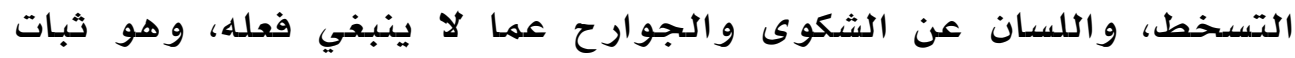

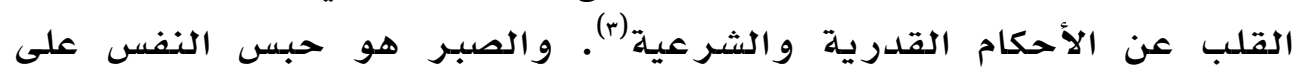
الطاعة، وكفها عن المعصية والرضى بقضاء الله وقدره من دون شكوى فيه

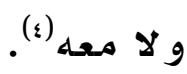

جاء هذا مـن خلال معالجة رسول الله صلى الله عليه وسلهم رحادثة الإفك دون أن يبرئ أو يتهم أحدا حتى جاء الحسهم مـن الله تعالى. أما ولهاء

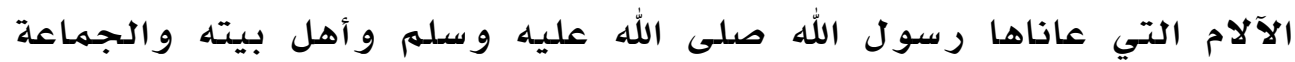

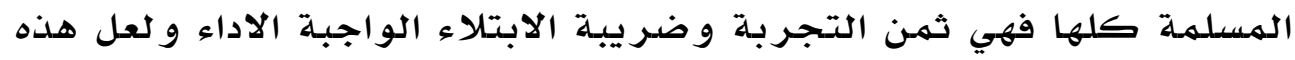

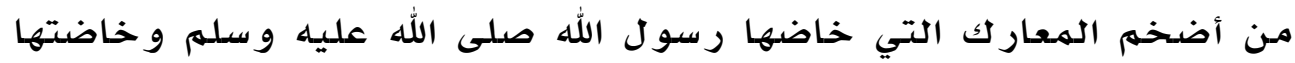

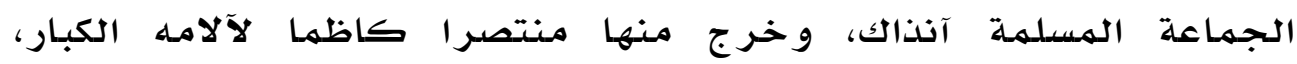
محتفظا بوقار نفسه وعظمة قلبه و وجميل صبره، فلهم تؤثر عنه كلهمة

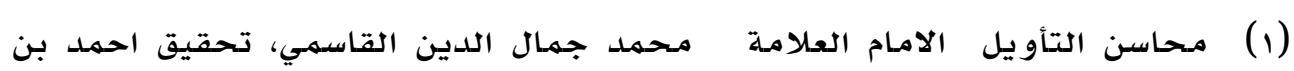

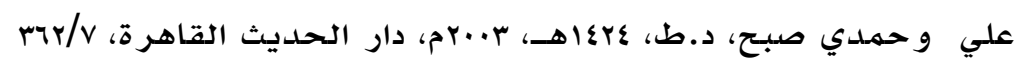
197/1 (r) تفسير ابن كثي (r)

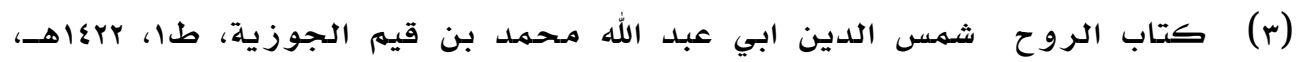

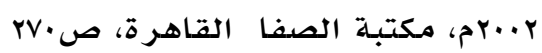

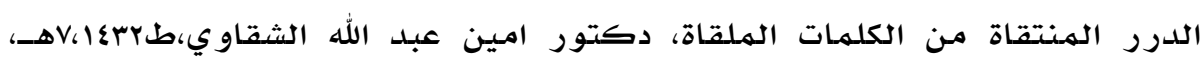


واحدة تدل على نفاد صبره وضعف احتهاله والآلام التي تناوشه لعلها

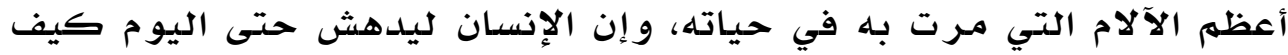

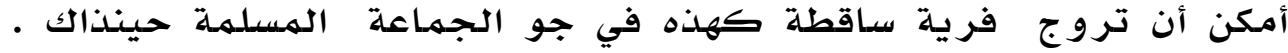
وأن تحدث هذه الآثار الضخمة في جسم الجماعة، وتسبب الآلام القاسية لأطهر النفوس و أكبر ها على الاطلاق (1).

\section{المطلب الخامس: الاستجابة للحق والرجوع للفضيلة}

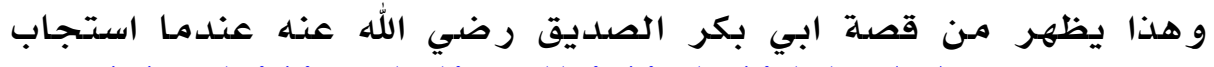

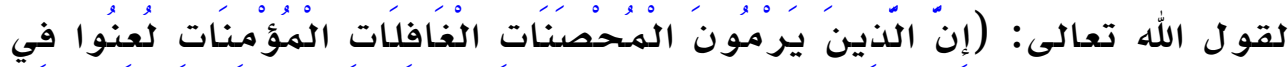

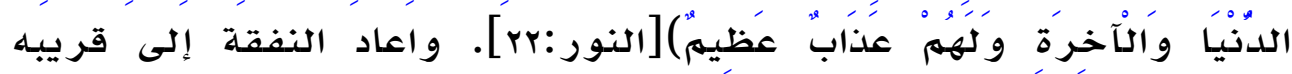

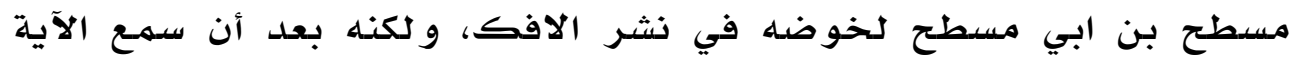

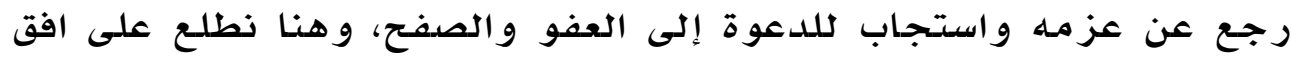

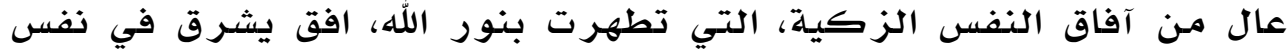

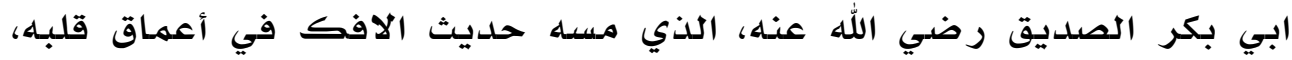

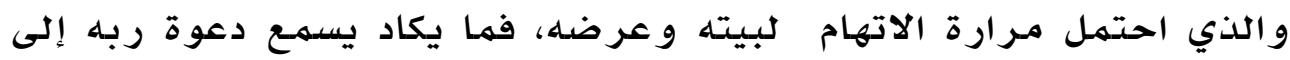

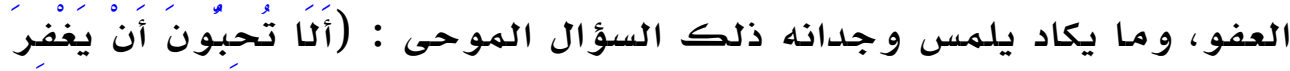

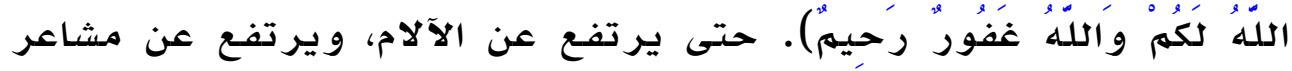
الإنسان، ويرتفع عن منطق البيئة وحتى تشف روحه وتر وف و وتشرق بنور

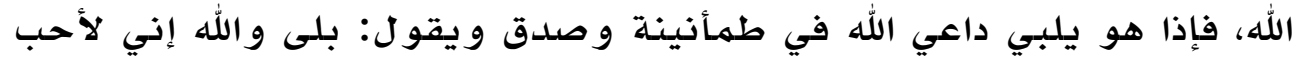
أن يغفر الله لي، ويعيد إلى مسطح النفقة التي كانت تنفق عليه، ويحلف النه

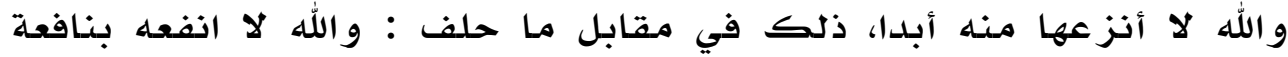

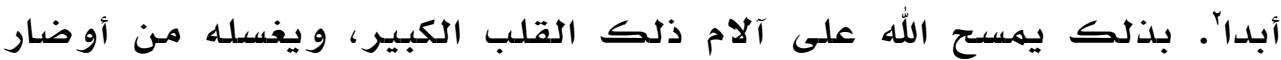

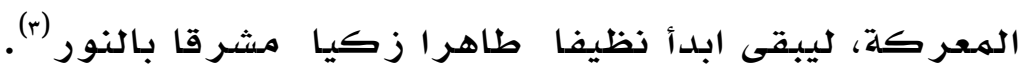

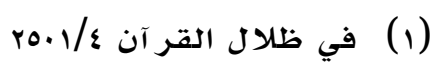

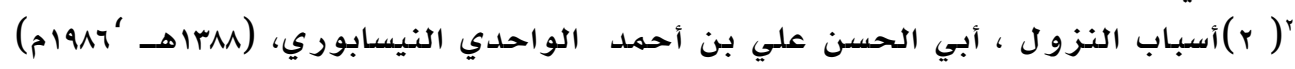

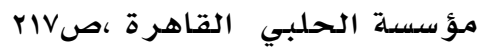

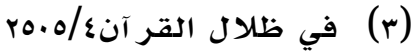


المبحث الثالث: الإصلاح السلوكي للفرد في سورة النور:

المطلب الأول: تعريف السلوك لغة واصطلاحا

\section{- تعريف السو ك لغة:}

السلوك في اللغة حسب ما ورد في لسان العرب هو من المصدر للفعل

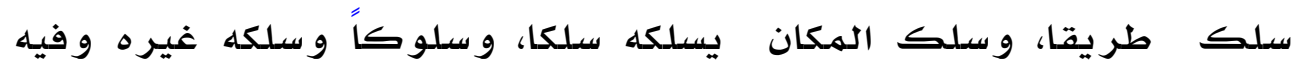
و أسلكه إياه و فيـه و عليه (1).

\section{- - تعريف السلولك اصطلاحا:}

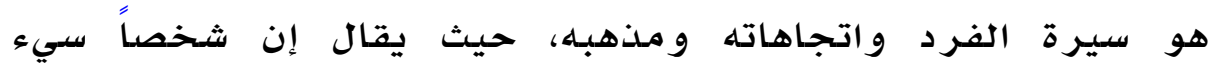

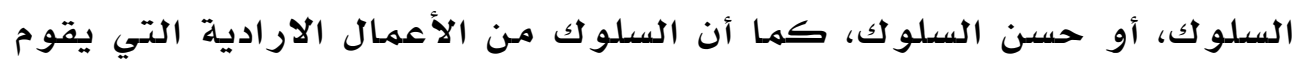
بها الإنسان كالكذب، و الصدق، و الكرم و البخل ولكل ونحو ها.

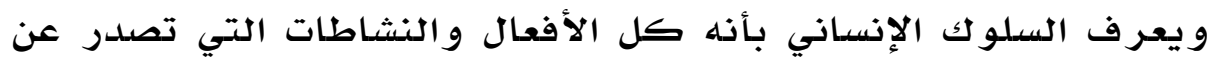

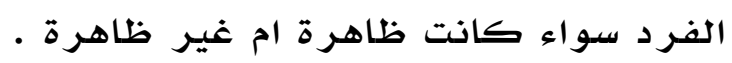

ويعرفه آخرون بأنه أي نشاط يصدر عن الإنسان سواء كان أفعالا

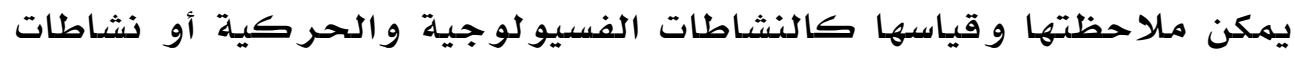
تتهم على نحو غير ملحوظ كالتفكير والتذكر والوساوس وغيرها وها.

\section{المطلب الثاني: غض البصر:}

-تعريف غض البصر: غض: الغين والضاد أصلان صحيحان، يدل احدهما على كف و نقص، والآخر على طراوة فالأول الغض، غض غض البصن البصر

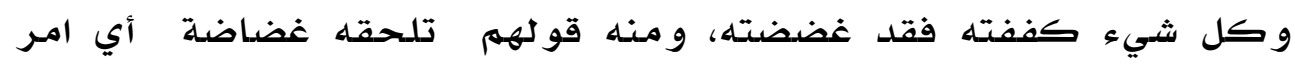

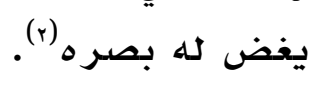

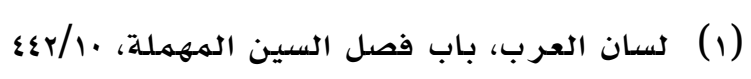

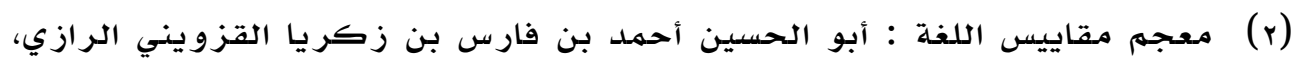

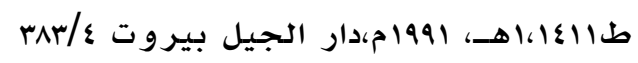


-و ايضا غض بصره، كفه وخفضه وكسره وقيل الغضيض الطرف

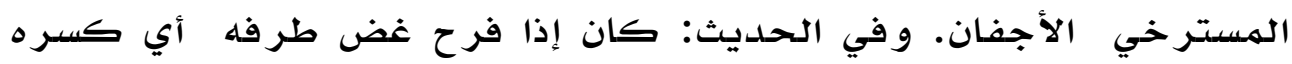

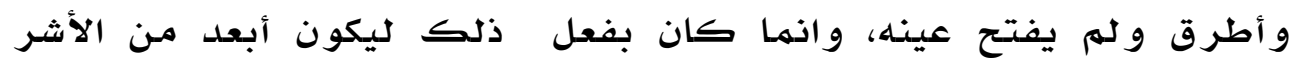

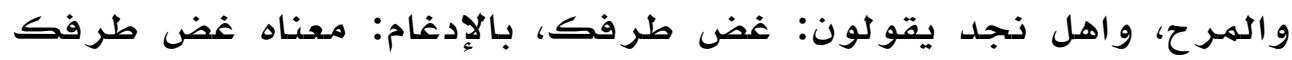
و لا مهانة(1). و غض الطرل الطرف احتهال المكروه (r).

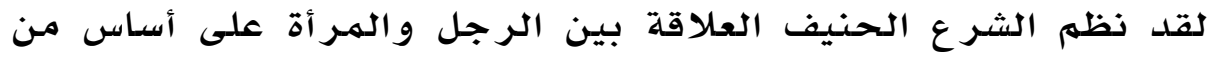

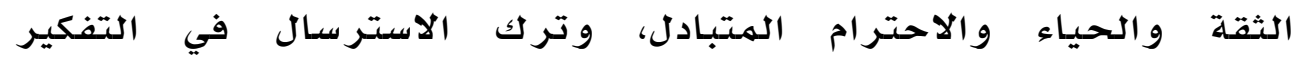

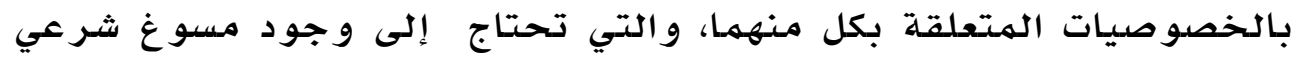

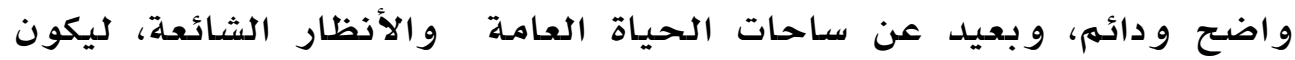

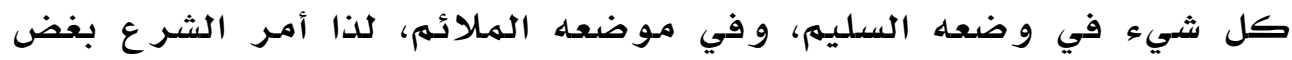

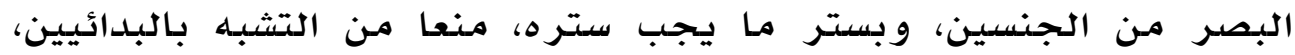

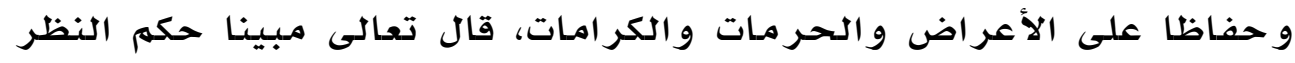

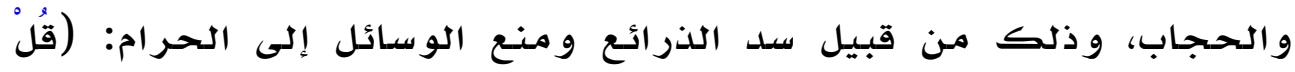

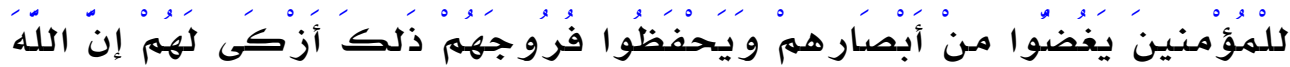

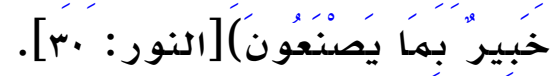
نزلت هذه الآية في رجل وامـرأة تبادلا نظرات السوء، زاعمين أنهما

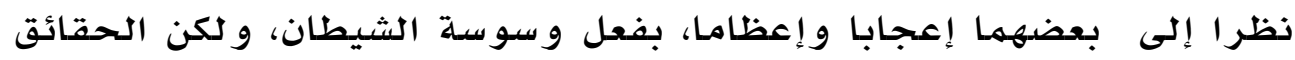

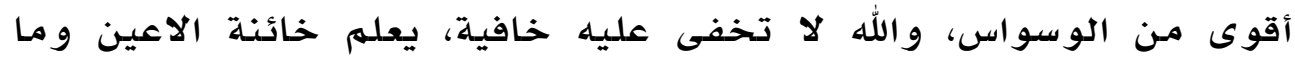

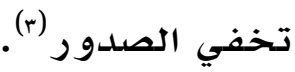
من الهعلوم ان لقلب الإنسان منافذ عدة، ومن أخطر هذه الهنافذ

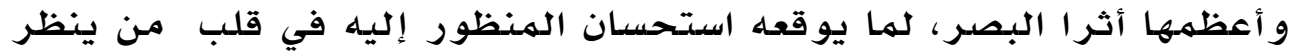

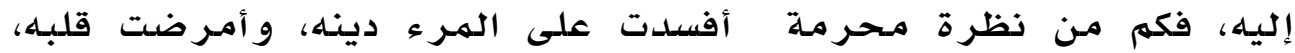

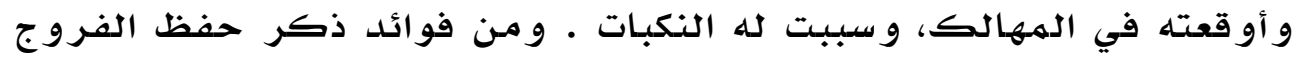

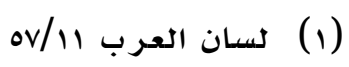

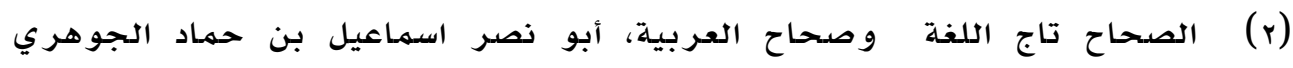

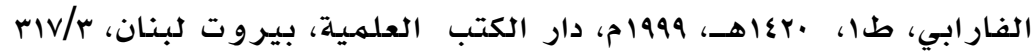

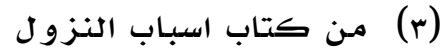


بعد غض الأبصار، ان اطلاق البصر فيهـا حرم الله مـن أعظم و أقوى أسبـاب

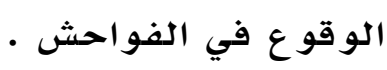

وقد وردت أحاديث كثيرة عن النبي صلى الله عليـه وسلهم توجه الهسلهم وتحثه على التزام هذا الأمـر الالهي، ومسن ذلك: مـا رواه عبد الله بن عباس رضي الله عنهها ق قال: "كان الفضل بن عباس رديف رسول الله صلى الله عليـه وسلهم، فجاءته امـر أة مـ خثعهم تستفتيه، فجعل الفضل ينظر إليها و تنظر إليه، فجعل رسول الله صلى الله عليه و سلهم يصرف وجـه الفضل إلى الشق الآخر ...."(1).

لذا أمـر الله تعالى نبيه محهما صلى الله عليه وسلهم أن يقول للمؤمنين: كفوا أو غضوا أبصاركه، فلا تنظروا الا إلى مـا أبيح النظر إليـه. والمعنى: قل لهم: غضوا يغضوا. و الغض لبعض الأبصار، لتوبيخ من

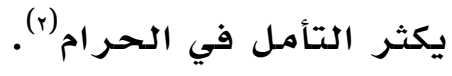

غض البصر مـن أجل الأدوية لعلاج أمـر اض القلوب. وفيه حسهم لهـادتها قبل حصو لها. فإن النظرة سهم مسهوم من سهام ابليس.. ومن أطلق لحظاته، دامت حسر اته

و كل الحوادث مبداها النظر .. ومعظم النار مـن مستصغر الشرر

قال الإمام بن القيهم رحمه الله في (الجواب الكافي)(r): في غض البصر

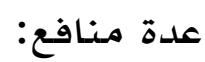

أحدها: امتثال أمـر الله الذي هو غاية سعادة العبد في معاشه و معاده.

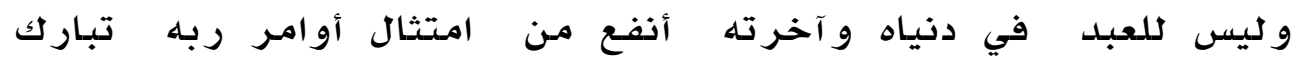

(1)صحيح مسلم كتاب الحج باب الحج عمن لا يستطيع الركوب رقم عrسا

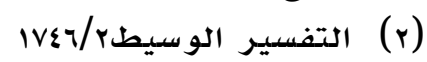

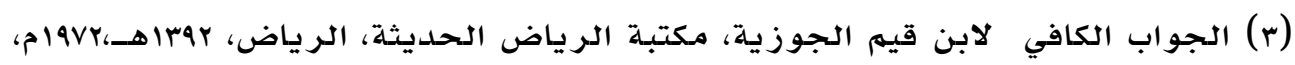




\section{مجلة معالم الدعوة الإسلامية المحكمة- العدد (الثاني عشر)- ربيع الثاني rعاهـ / ديسمبر •r.r.}

وتعالى. و مـا سعد من سعد في الدنيا والآخرة، إلا بامتثال أوامر ربـه. و مـاشقي من شقى في الدنيا والآخرة الا بتضيـيع أوامـره.

الثاني: أنه يهنـع مـن وصول أثر السهم الهسهوم، الذي لعل فيـ

$$
\text { هالاكه لا إلى قلبـه. }
$$

الثالث: أنه يورث القلب أنسا بالله، فإن إطلاق البصر يفرق القلب و يشتته و يبعده مـ الله، وليس على العبد شيء أضر مـن اطلاق البصر فإنه يوقع الوحشة بين العبد وربه.

الرابع: انه يقوي القلب ويفرحه. كها ان اطلاق البصر يضعفه و ونحز ذه

الخامس: اذه يكسب القلب نورا كها ان اطلاقةه يكسبـه ظلهمة و لهذا

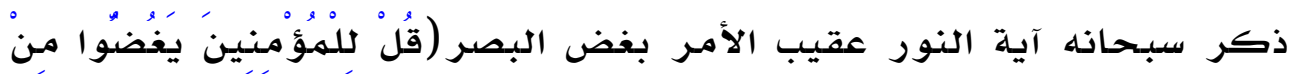

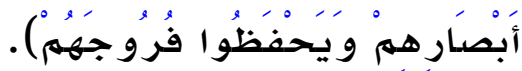

ثم قال أثر ذلك قوله تعالى: (للّهُ نُورُ السهمَاوَات وََالأرض) [النور:هr]. "أي مثل نوره في قلب عبده الهؤمن، الذي امتثل أوامـره

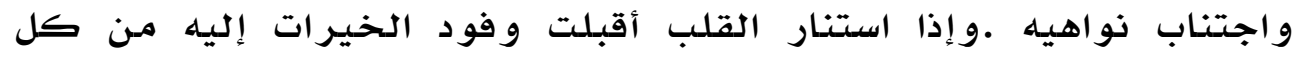
جانب. كها إذا أظلهم أقبلت سحائب البلاء و الشر عليه مـ كل مكان. فها شئت مـن بدعة وضدلالة، واتباع هوى واجتناب هدى، واعراض عن أسباب السعادة، واشتغال بأسباب الشقاوة، فان ذلك انها يكشفه النور الذي في القلب، فإذا فقد ذلك النور بقى صاحبـ كالأعهى الذي يجوس في حنادس

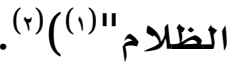

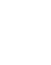




\section{المطلب الثالث: حفظ الفرج}

و أمر الله تعالى المؤمنين بحفظ فروجهم من من الفواحش والشذوذ

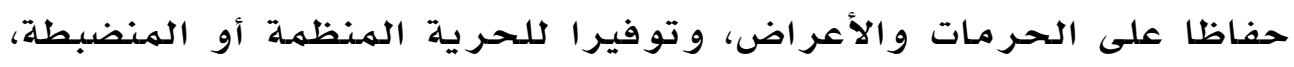

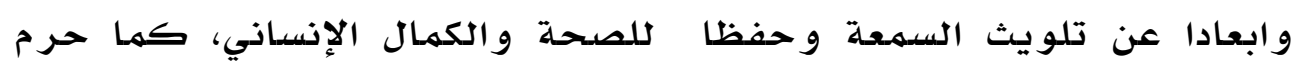

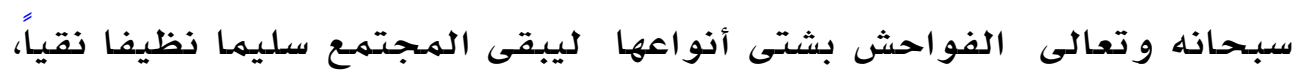

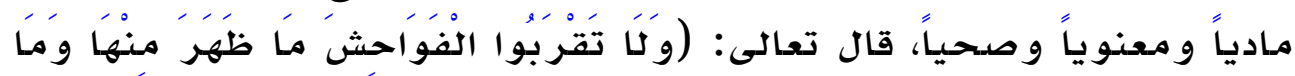

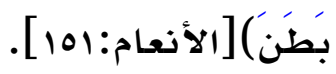
و قال صلى الله عليه وسلهم: "من أشراط الأنعالساعة أن يرفع العلهم ويظهر

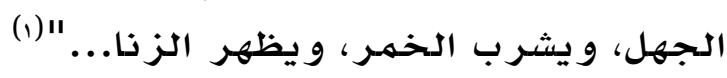

و لعل الحكمة من تحريم الزنا إنه إذا أثبع الرغبـات الجنسية، الا انه لا

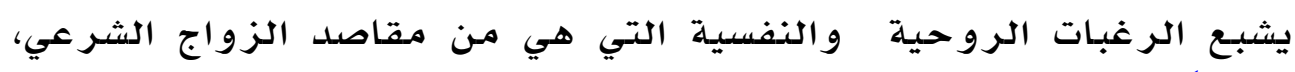

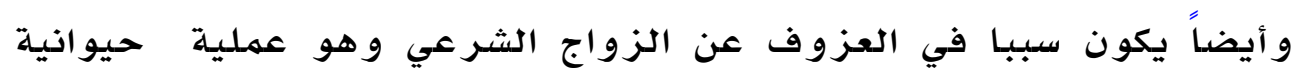

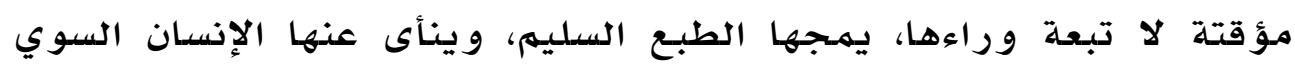

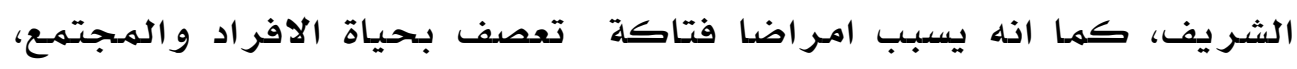

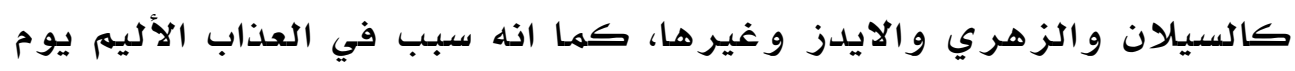

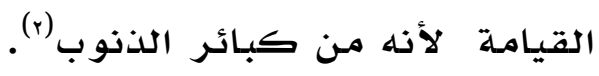

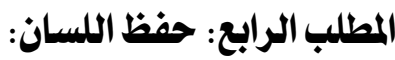

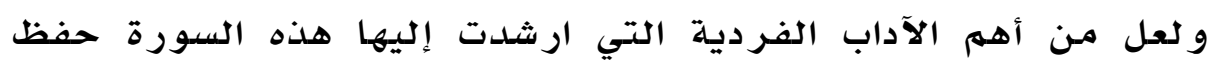

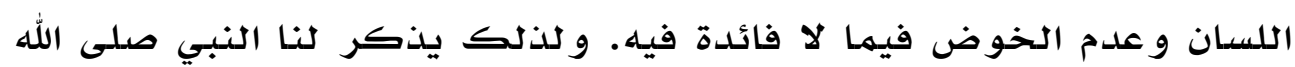

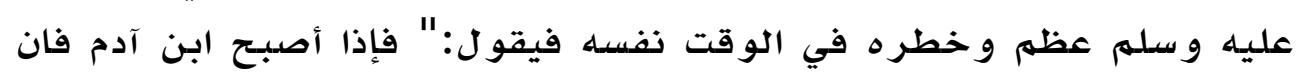

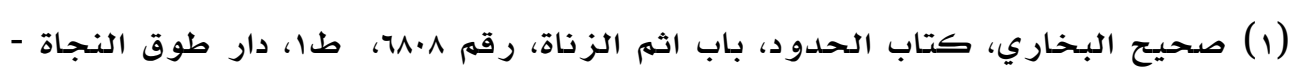

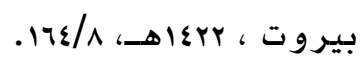

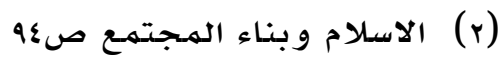


الاعضاء كلها تكفر اللسان فتقول اتق الله فينا فإنما نحن بك فان استقهت

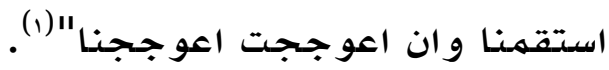

فحظ اللسان: هو صون الإنسان لسانه عن كل خطأ يغضب الله من كذب و غش و نهيمهة وقذف .

فان مـن نعم الله العظيهمة على الإنسان، نعمهة اللسـان، وهذا اللسـان ان لهم

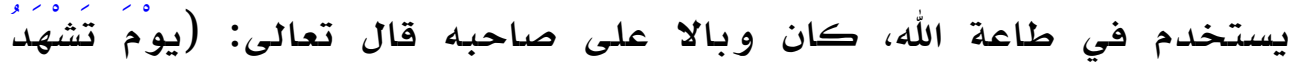

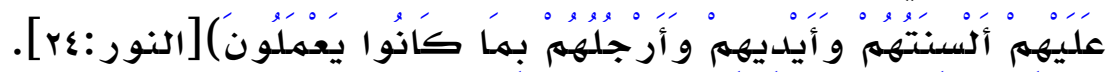
وقد وردت نصوص كثيرة تحث على حفظ اللسان، قال تعالى: (مَأ

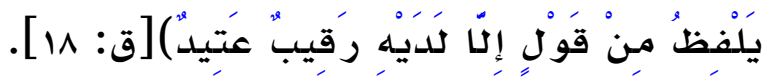
وروى الترمدي من حديث معإذ رضي الله عنه: أنه سأل النبي صدلى الله عليه وسلهم عن عمل يقربه إلى الجنة ويباعده من النار؟ فأخبره النبي صلى الله عليـه وسلهم بر أس الأمر و عمهوده وذروة سنامـه، ثه قال: "ألا

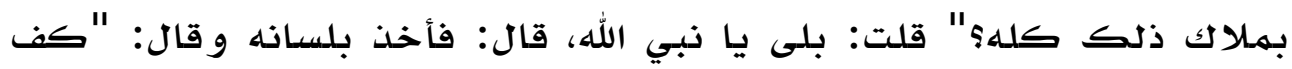
عليك هذا". فقلت: يا نبي الله، وانا لهؤاخذون بها نتكله به؟ فقال:" ثكلتك أمك يا معإذ، وهل يكب الناس في النار على وجوههم - أو: على

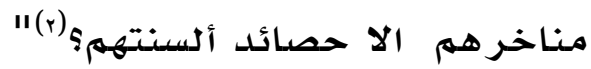

وايضـا حديث عقبه بن عامر رضي الله عنه قال:" قلت: يـارسول الله، حدثني بأمر اعتصدم بـه قال:" قل: ربي الله ثم استقهم"، قلت: يـارسول الله،

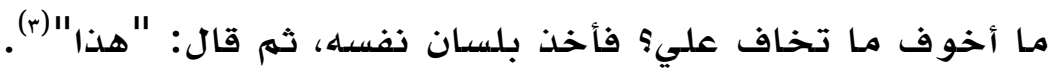

قال الإمـام النووي رحمـه الله: أعلهم انه ينبغي لكل مكلف أن يحفظ لسانه عن جميع الكلام الا كلامـا تظهر المصلحة فيه، ومتى استوى الكلام وتركه في المصلحة فالسنة الامساك عنه، لأنه قد ينجر الكلام المباح إلى

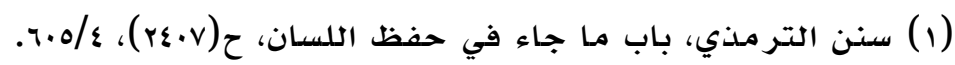

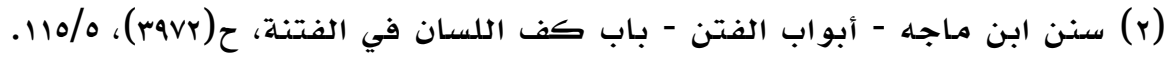

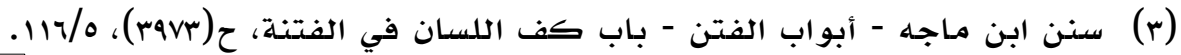


حرام أو مكروه، بل هذا كثير أو غالب في العادة، والسـلامهة لا يعدلها

قال بعض أهل العله: في اللسان آفتان عظيهتان، ان خلص مـن احداهها لهم يخلص من الاخرى، آفة السكوت عن الحق، أو آفة الكلام بالباطل، وقد تكون كل منهما اعظم من الاخرى في وقتها، فالسـاكت عن الحق شيطان

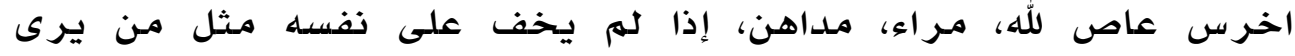
الهنكـر ات امـام عينيـه مـع قدرته على التغييـر ولا يفعل.

عن ابي سعيد الخدري رضي الله عنه: ان النبي صدلى الله عليه و سلهم قال:" من رأى منـكم منكر ا فليغيره بيده، فان لهم يستطع فبلسـانه، فان لهم

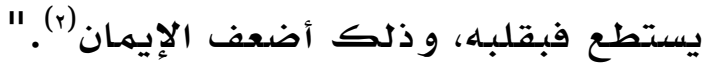

الآفة الثانية: التكلم بالباطل، وهو شيطان ناطق عاص لله، وأكثر الخلق منحرف في كاملامه وسكوته، فهم بين هذين النوعين، وأهل الوسط هم أهل الصر اط الهستقيه، كفوا السنتهم عن البـاطل، و أطلقوها فيهـا يعود عليهم نفعه في الآخرة، فلا يرى أحلدهم يتكلم بكلمهة تذهب عليـه ضائعة بلا

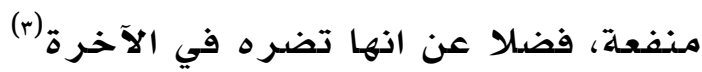

ففي سورة النور اشـارة واضحة إلى حفظ اللسـان والتثبت و عدم اطلاق الشائعات، ان ترك الالسنـة تلقي الالسنـة التهم هكذا جزافي على الهحصنات وهن العفيفات الحرائر، يترك المهجال فسيحا لكل مـن شاء أن يقذف بريئة أو بريئا بتلك الجرائم والتهم النكراء وان هذا ليؤدي بالهسلهين إلى خطر عظيه، فأعر اضهم مسروحة وسهعتهم ملوثة. من اجل حفظ ذلك كله اوقع الشارع الحكيهم فيهـن أطلق لسـانه في اعراض الهسلهـين حد (1) التصوير القر آني للقيم الخلقية و التشر يعية، علي صبح، المكتبـة الأزهرية للتراث،

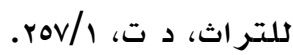

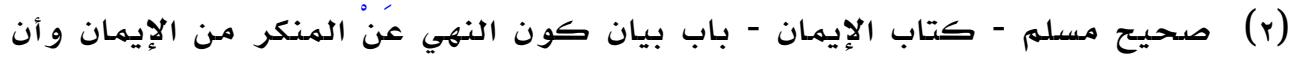

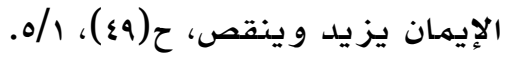

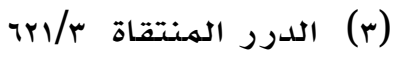


القذف، وهو الجلد ثمانين جلدة جزاء على فعلته، فضلا عن جعله من الفاسقين الذين ترد شهادتهم فلا تقبل. الإطلب الخامس: الحشمة والعفة - ستر الزينة للقواعد.

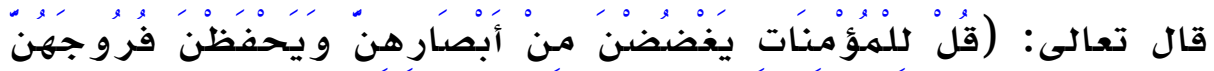

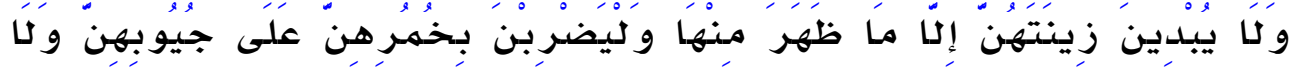

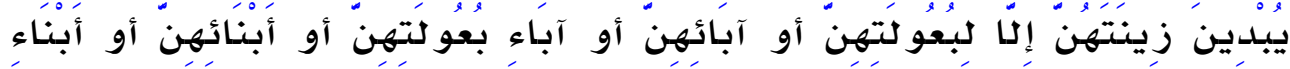

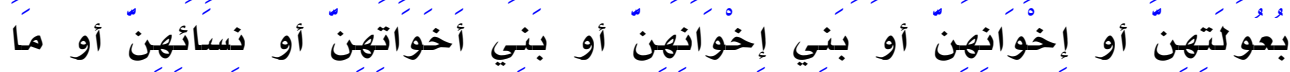

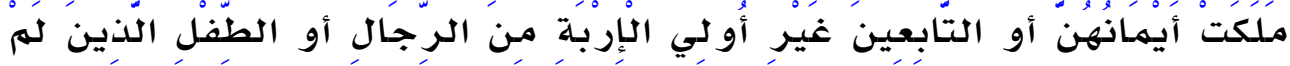

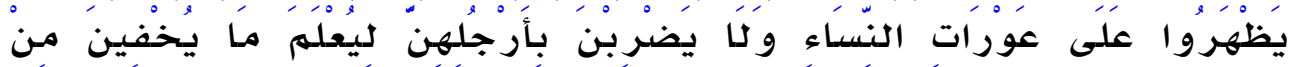

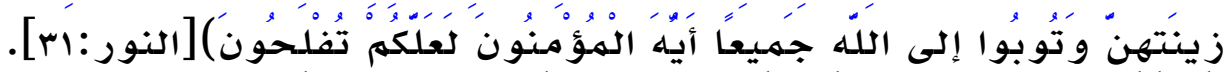

أي و لا يظهرن للناس الذين ليس لهن بهحرم زينتهن، وهما زينتان: احداهما: مـا خفي، وذلك كالخلخال والسوارين والقرطين و القلائد، و الأخرى: ما ظهر منها، وذلك مسختلف في المعني منه بهذه الآية، فكان

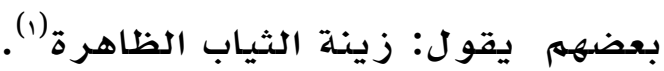

و لعل مـا ورد في الآية كما ذكر ابن كثير: هو أمر مـن الله تعالى

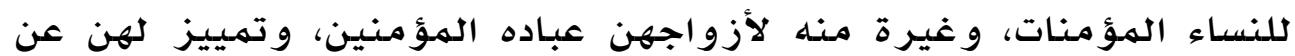

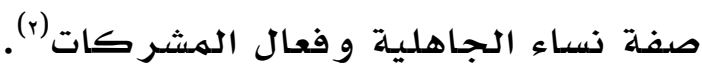

و لعل سبب نزول هذه الآية ما ذكره مقاتل بن حيان قال: بلغنا و الله أعلى

أن جابر بن عبدالله الأنصاري حدث إن أسهماء بنت مرشدة كانت في محل لها في بني حارثة، فجعل النساء يدخلن عليها غير متأزرات فيبدو

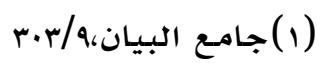

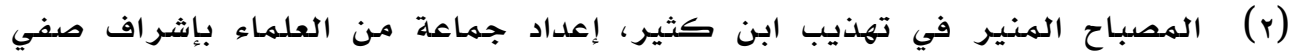

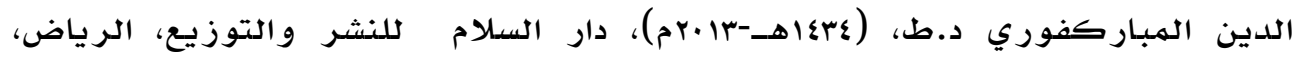


مـا في أرجلهن مـن الخلاحل وتبدوا صدوورهن وذووائبهن، فقالت أسهـاء:" مـا أقبح هذا." فأنز ل الله تعالى هذه اردئية(1).

\section{الهطلب الخامس: الغيرة على العر ض و الحر مـات:}

إن غيرة الرجل على مهارمـه و عر ضـه مـن العوامل الههمهة و والوسـائل الناجعة في حماية الأسرة والافراد من الانحراف و والتعرض لأسبابه ودواعيـه، ووكلها قوي الإيهان في قلب المؤمن قويت عنده الغيرة وزادت، و هي تنقص بنقص الإيهمان، بل قد تتلاشى و وتضهحل بسبب ما يقترفه العبد من الذنوب، ولهذا عد ابن القيهم ذهاب الغيرة أثرا مـن آثار الذذوب و الهعاصي فقال: "و مـن عقوباتها انها تطفئ من القلب نار الغيرة التي هي لحياته و صلاححه كالحر اة الغريزية لحياة جهيع البدن... إلى أن قال: اشرف الناس و أعلاهم قدرا و ههة اشدههم غيرة على نفسه وخاصسته وعموم (r) (الناس)

والغيرة من صفات الرب جلا وعلا، وروى أبو هريرة رضي الله عنـه أن النبي صلى الله عليه وسلهم قال:" ان الله يغار، وغيرة الله ان يأتي الهؤمن مـا حر م الله (r). "و عن ابي مسعود رضي الله عنه عن النبي صلى الله الله عليه وسلهم قال: "مـا من أحد أغير من الله مـن أجل ذلكو ذلك حرم الفواحش، و مـا أحد أحب إليه الهدح من الله (ع)." ومن الهعلوم أن النبي صلى الله عليه

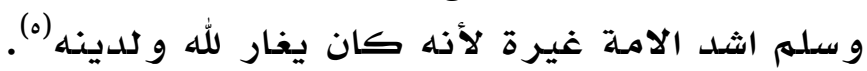

التَّنَسيرُ البَسِيْط: أبو الحسن علي بن أحمد بن محمد بن علي الواحدي،

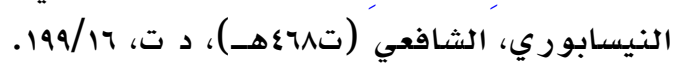

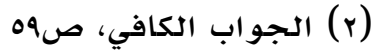

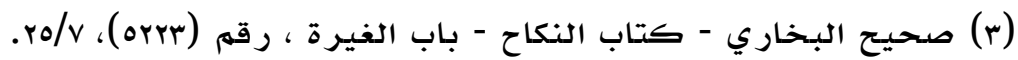

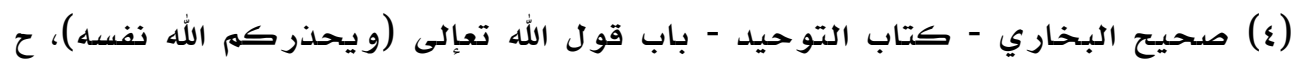
.1r./4، (v\&.r)

فتح البارئ في شرح صحيح البخاري، العسقلاني، هاءاهـ، 199Vم،الرياض مكتبة 
وقد قال عليه الصلاة و السلام لأصحابه:" أتعجبون مـن غيرة سعد؟

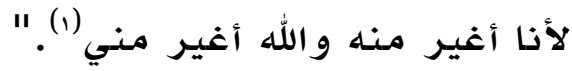
وقد دل هذا الحديث على قوة وشدة غيرة سعد بن عبادة رضي الله عنه، و قد قال رسدول الله صدلى الله عليه و سلهم هذا القول عندما سهـع سعد

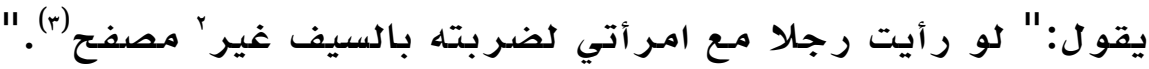

و لقد شهد النبي صلى الله عليه وسلهم للبعض مـ أصحابه بشدة الغيرة، كها شهد بها لسعد بن عبادة، ومنههم: عمر بن الخطاب رضي الله عنه، قال: "بينهما نحن عند رسول الله صلى الله عليه وسلهم جلوس، فقال رسول الله صلى الله عليه وسلهر:" بينها أنا نائهر رأيتني في الجنهة، فإذا امر أة تتوضأ إلى جانب قصر، فقلت: لهن هذا؟ قال: هذا لعمر، فذكرت غيرتك، فو ليت مدبرا." فبكى عمر وهو في الهـلس ثم قال: أو منك يا

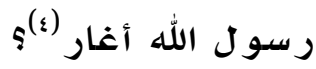

و الغيرة الهحمودة هي التي تكون في الريبـة، أمـا الغيرة مـن غير ريبـة فهي هوس وظن فاسلد، وهي مـذمومـة يكر هها الله تعالى، قال عليـ الصـلاة و السـلام: "ان مـن الغيرة مـا يـحب الله، ومنهها مـا يكره الله، فالغيرة التي يحبها الله الغيرة في الريبة، و الغيرة التي يكره الله، الغيرة في غير ريبـة(ه). فعلى أو لياء النساء أن يدركوا ذلك فلا يطلقوا لأنفسهم العنان بإسـاءة الظن في نسائهم وبناتهم دون دليل وبرهان، و ليعلموا ان الغيرة

(1) صحيح البخاري، كتاب النكاح، باب من رأى مـ امر أته رجلا فقتله ،رقم $1 \mathrm{Vr} / \mathrm{T} \Sigma \mathrm{T}, \Lambda$

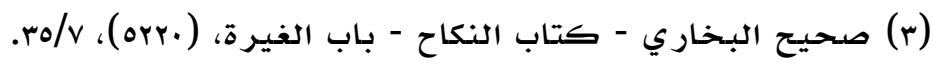

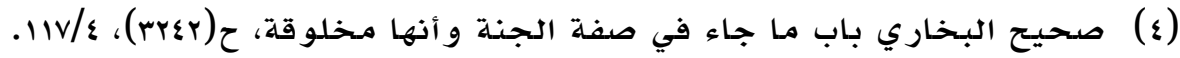

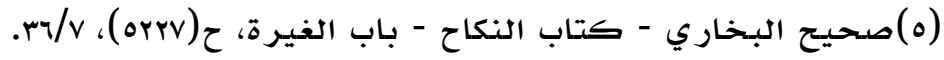




\section{مجلة معالم الدعوة الإسلامية المحكمة- العدد (الثاني عشر)- ربيع الثاني rعاهـ / ديسمبر •r.r.}

دون شيء مـريب، هي مـجرد اسـاءة ظن وتهمهة لا صحة لها، وان ذلك يضر و لا ينفع، و يفسد العلاقة بين الزو جين ونين الأقر بـاء (1).

وقال الدكتور أحمد الشرقاوي: وغيرة الرجل على أهلـه أمـر واجب،

و للغيرة حدود و ضوابط، فهي غيرة معتدلة، غيرة لا تلقي بصاحبها في خضهم الشك وظلهات الوهم، لأن الاصل في المعاملة حسن الظن والثقة بالغير ما لم يثبت خلاف ذلك، وكم من بيوت قد تهدمت، ووكم من أسر

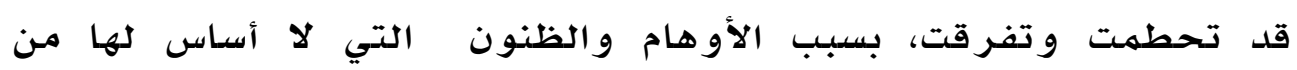
الهسحة) (r)

الخاتمة:

في ختام هذا البحث الذي تناول الإصدلاح الفردي في سورة النور، لاشك أن السورة تناولت العديد من جوانب الإصلاح الفردي أبرزها الإصدلاح الأخلاقي والسلوكي ويهكن من خلاله أن نتوصل إلى النتائج والتو صيات الآتيـة:

|النتحائج:

/ ان سورة النور قد حظيت بـاهتمام تشريعي خاص إذ افتتحت بافتتاحية ميزتها عن غيرها من السور القر آنية و أكدت على فر ضيـة احكامها و ما جاءت بـه من تشريعات لهـالح الفرد و الهـتهمع، وقد وردت عدة روايات تؤُكد اهمية تعلمها و العهل بأحكامها . r/اظهرت السورة تفرد القر آن الكريهم بهنهج تربوي شامل متكامل فهو يهتهم بجوانب النفس الإنسانية والروحية والأخلاقية و السلو كية كها عهلت على تقوية صللة الفرد بربه وبالآخرين. (1) الاسلام و بناء الهجتمـع، الدكتور حسن عبد الغني ابو غدة و آخرون، طهبـا،جهـ-

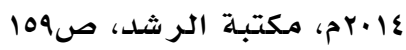

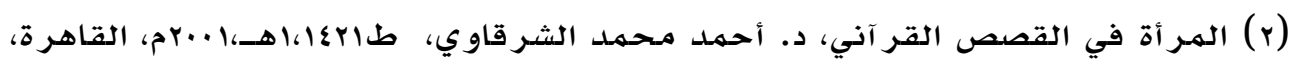
$r \leqslant 9$

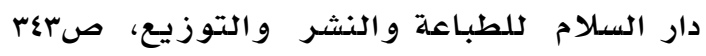


ץ/ كها ان سورة النور دعوة هادفة إلى اضساءة القلب بنور الله وذكره، وتذكر جلاله وعظهته، وهي سياج للفرد والهـتهـع من الانحلال والتردي في الخطيئة فقد امرت بغض البصر وحفظ الفرج، و نهت عن قذف الهـحصنات وبينت عقوبـة البهتان والصساق التههم الكاذبة، و ذمت إشاعة الفاحشة، وحثت على التوبة والانابة و بذلك اخذت بيد الإنسان إلى الطريق الصحيح ورفعت عنسه عوامل الاحبـاط والانتكاس

$$
\text { و بينت ان الله مطلع على كل شيء. }
$$

ع/حر ص الصحابة على تعليهم نسائهم سورة النور لها فيها مـن ووصايا

$$
\text { و إرشادات مههـة . }
$$

\section{التوهيات:}

ا/ لابد من غض البصر وحفظ الفرج لأن حفظهما صدون للإذسـان و المهجتهـع من كل فاحشة. r/ تعليهم الأبناء هذه الآداب وبخلاف ذلك سيتم تعلم الآداب الدخيلة و الهستورددة التي لا تتتناسب مـع عادات الهسلهين. ب/ على الهسلهم ان يوقر النبي صلى الله عليه وسلم حيا وميتا و أن يقدم محبته على مححبة النفس و الاهل والولد حتى يستكمل الإيهان. ع/ الحرص صلى علدم خوض الإنسان بكلامهـ فيما لا فائدة فيه، وتر كك فضول الكلامث ه/ التعمق أكثر في مضـامين سور القر آن الكريهم لها فيها من الآداب و القيهم التي تبني الأفراد وتنظمم المهتتمعات و هذا القر آن لا تنقضي عجـائبه فهو صالح لكل زمان ومكان. 


\section{قائمة المصادر والمراجع:}

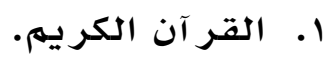

r. الأخلاق الإسلامية وأسسها، عبد الرحمن حسن حنبكة الميداني،

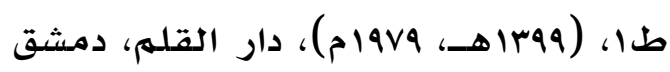

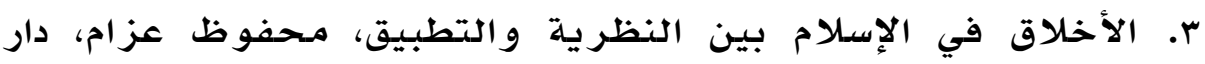

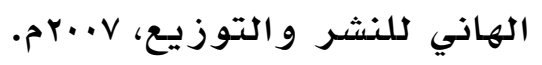

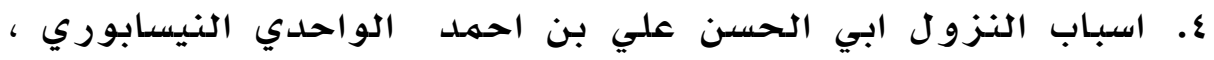

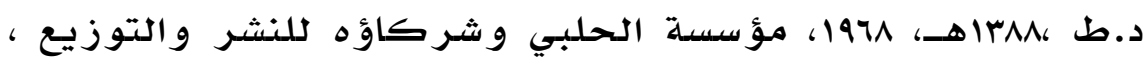
القاهرة

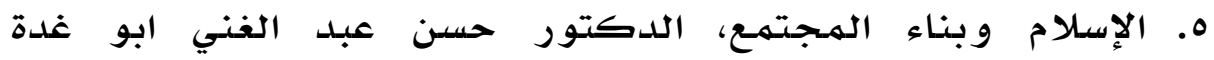

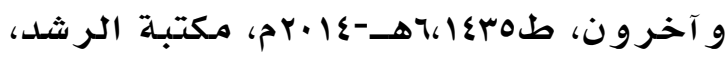

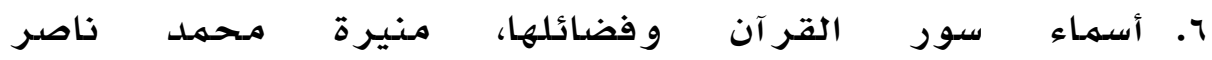

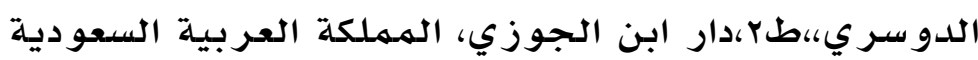

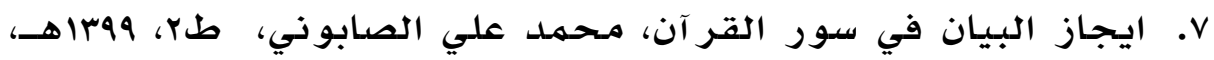

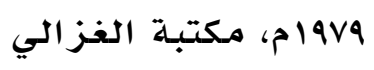

^. بصائر ذوي التمييز، مجد الدين محمدد بن يعقوب الفيروز ابادي

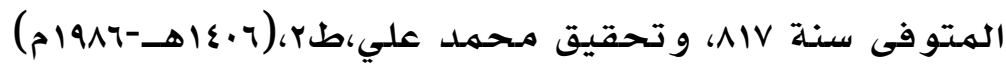

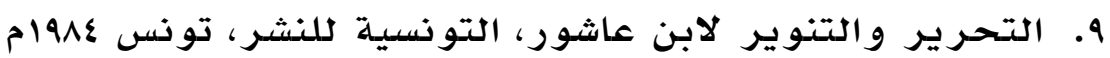

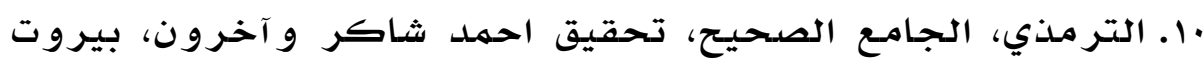

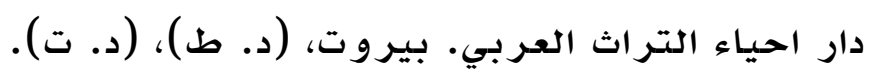

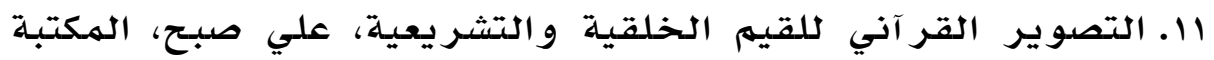

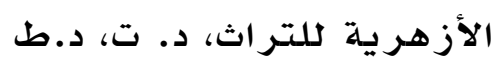

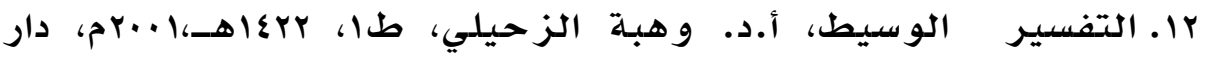

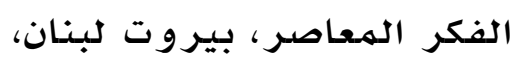

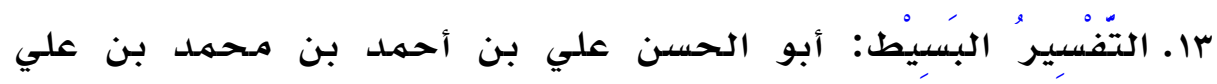

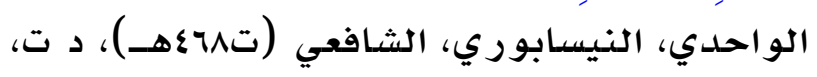

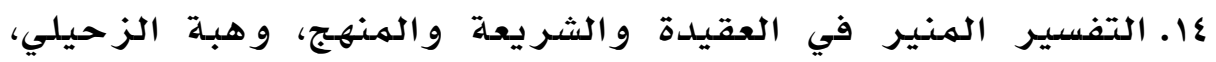




$$
\text { ط^، دار الفكر - دمشق، }
$$

10. جامـع البيان في تأويل القر آن، لابي جعفر محمد بن جرير

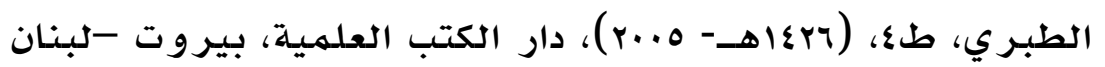

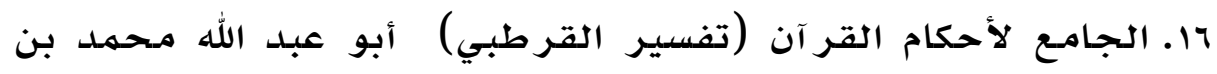
أحمد بن أبي بكر بن فرح الأنصساري الخزرجي شهس الدين القرطبي (ت: آلهـ) تحقيق: أحمد البردوني و إبراهيهم أطفيش، طץ، ع^اוهـ - ع797م: دار الكتب الهصرية - القاهرة Vا. جمهرة اللغة، أبوبكر محهد بن الحسن بن دريد الازدي،

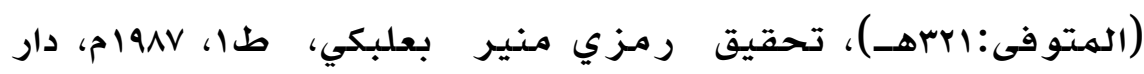

$$
\text { العلهم للهملايين بيروت }
$$

11. الجواب الكافي لابن قيهم الجوزية، مكتبة الرياض الحديثة،

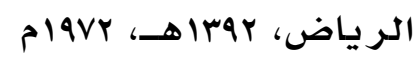

19. دراسـات في التفسير الموضوضوعي للقر آن الكريه، الدكتور زاهر بن

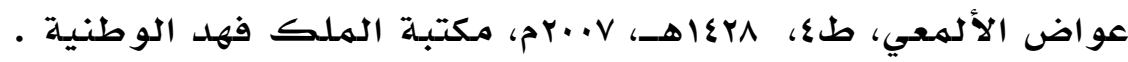
•r. الدرر الهنتقاة من الكلهمات الهلقاة، دكتور امين عبد الله الشقاوي،

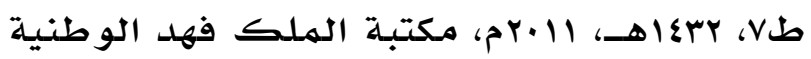

اب. سلسلـة الاحاديث الصسحيحة، محمدل ناصر الدين الالبـاني، طا، مكتبـة

$$
\text { المعارف }
$$

بr. سنـن ابن مـاجـ: ابن مـاجـة أبو عبد الله مححمد بن يزيد القزويني،

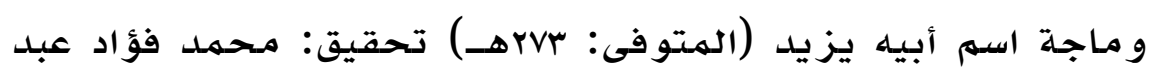

الباقي، دار إحياء الكتب العربية - فيصل عيسى البابي الحلبي. سب. السنن الكبرى للنسـائي، أبو عبد الرحمن أحهد بن شعيب النسـائي،

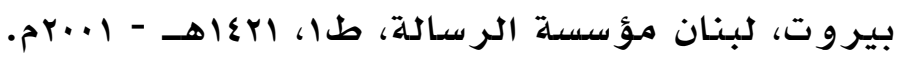
ع . الصسحاح تاج اللغة وصحاح العربية، أبو نصر إسهاعيل بن حماد

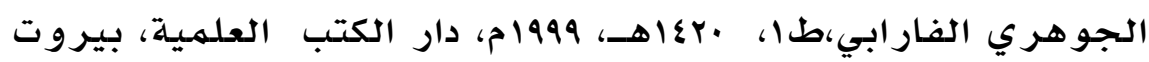

$$
\text { لبنان }
$$

هr. صحيح مسلم، الرياض، دار النشر و التوزيع، (طr)، (باعاهـ) جr. صحيح البخاري، الرياض: دار السلام للنشر التوزيع، 


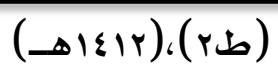

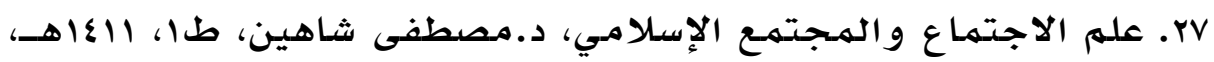

^ץ. علوي بن عبد القادر الستّاف، تخريج أحاديث و آثار كتاب في ظلال القر آن، "لسيد قطب"، دار الهجرة للنشر والتوزيع، طب،

$$
\text { . } 1990-01 \leqslant 17
$$

وץ. عمدة القارئ شـرح صحيح البخاري للشيخ بلدر الدين محممد مـحمود

$$
\text { العيني (تهرهـ، دار الفكر بيروت لبنـان }
$$

•r. فتح البارئ في شرح صحيح البخاري، ابن حجر العسقلاني،

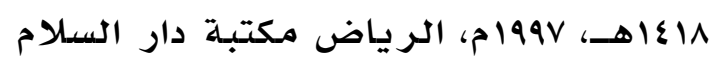

اس. في ظلال القر آن: سيد قطب إبراهيم حسين الشاربي (تهیراهـ)،

$$
\text { طVا- - إعاهـ، دار الشروق - بيروت- القاهرة. }
$$

ץس. كتاب الثقافة الإسـلامية، اعداد مـجمو عة من العلمـاء و الباحثين، مر كز الر عاية والتحصين الفكري، طا، وبعاهـ، 11 +rم، الخرطوم

$$
\text { شر كة مطابع العملة }
$$

سم. كتاب الروح شهس الدين ابي عبد الله محهد بن قيم الجوزية،

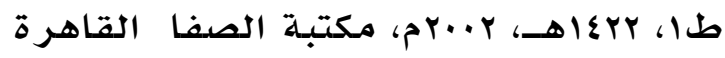
عا. كشاف اصطلاححات الفنون و العلوم، العلامهة محمدد علي التهانوي، تحقيق علي دحروج، د.ط، د.ت، مكتبـة لبنان

هr. لسـان العرب، طا، د ت، دار صادر، بيروت

بس. مـحاسن التأويل الإمـام العلامهة محمد جمهال الدين القاسهي،

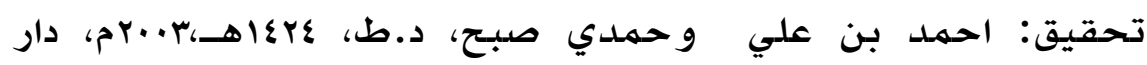

$$
\text { الححديث ، التقاهرة }
$$

VV. الهمحكم و المحيط الأعظم، أبو الحسن علي بن إسهاعيل بن سيده

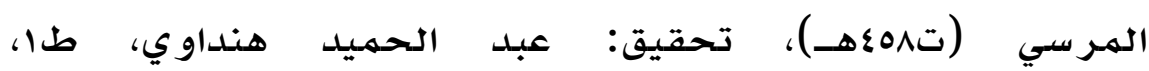

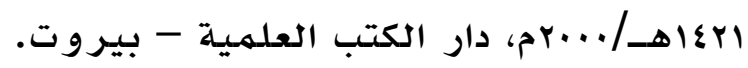

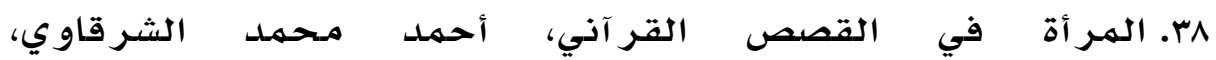

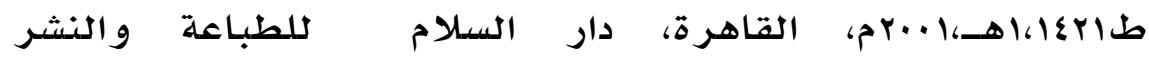




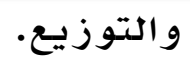

qه. المصباح المنير في تهذيب ابن كثير، اعداد جماعة من العلماء

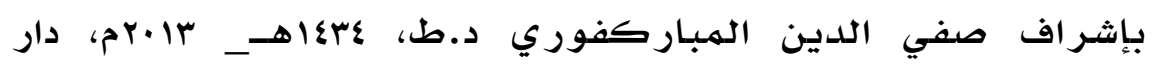

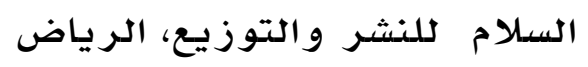

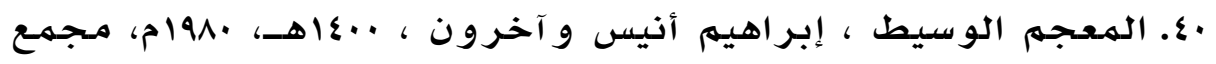

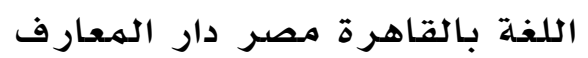

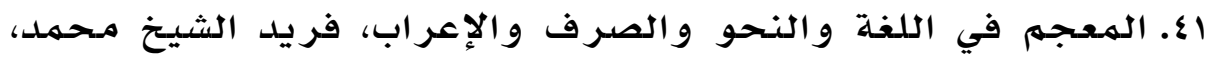

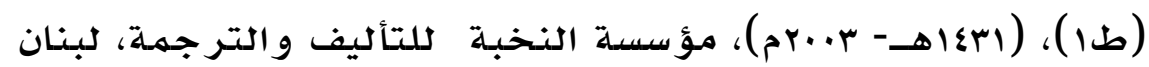

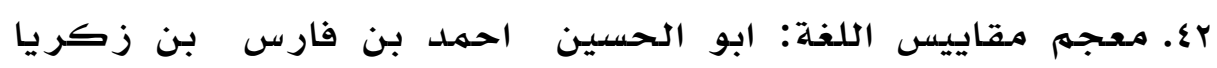

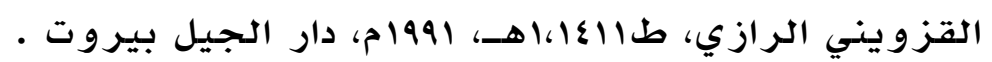

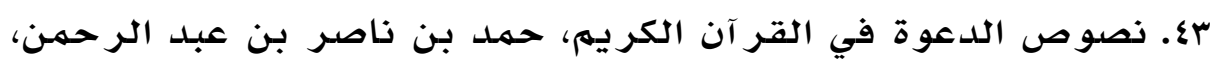

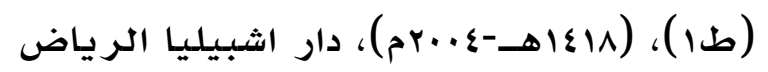

